\title{
Canadian and International Education Journal Index
}

\author{
Dien Tran (University of Western Ontario) \\ Chen Jie (University of Western Ontario) \\ Mohsen Mahmoudi (University of Western Ontario)
}

A tribute to Professor Douglas W. Ray (1932-2007)

It was in 1994, when Douglas Ray and David Radcliffe were co-editors of the Canadian and International Education Journal (CIEJ) that the idea of an Index for the journal was advanced. The task was initially planned for 1996, and as research associate to Douglas Ray, I was selected to compile this Index. However, Education for Human Rights, later published by the International Bureau of Education, UNESCO, then the third edition of the Social Change and Education in Canada a textbook for the Faculty of Education took away all my 20hour/week time.

It is thirteen years later that, as Administrative Assistant to the Journal Editor, that I could realize the dream. That was Suzanne's idea to get the Index published in this special third issue of Volume 36, to commemorate the 40th anniversary of the founding of the Comparative and International Education Society of Canada.

I was lucky to have the unfailing assistance and support of Ms. Chen Jie, and of Mr. Mohsen Mahmoudi. Both were equally dedicated to the job, eager to contribute long hours for this work, and above all, were never afraid to ask for clarification. Without them, this Index would not have been completed. I would like to acknowledge here the hard work and serious research of Ms. Chen and of Mr. Mahmoudi. They have done their best. Some mistakes and errors that may come to your attention are solely mine.

This Index includes all issues of the CIEJ, from volume 1 to volume 36 . Each entry has the author(s)'s name (s) and the title of the article. We tried to have the region, country, provinces or states as the first keyword, situating the article's scope within its geographical area(s). The keywords are kept within a reasonable length. Articles in French have also their "mots-clés" to facilitate the searches. At the end of the Index, you will find the three Proceedings of the Society (1967, 1968, and 1970), during its founding period. We could not locate the other two (1969 and 1971) and indeed, cannot ascertain whether they were ever produced.

We hope that you will find in this Index some of the necessary sources for your research, and the team would like to invite you to send us your comments and suggestions so the next Index will benefit from all and for all. 


\section{Volume 1, number 1, June 1972}

Katz, J. A multicultural curriculum for a cosmopolitan citizen. pp. 7-14.

Keywords: cosmopolitan curriculum; citizen; patriotism; multiculturalism

Entwistle, H. Problems of political education. pp. 15-14.

Keywords: political education; citizenship; associational democracy

Seybolt, P. J. China's revolution in education: The struggle between two lines.

pp. 29-41

Keywords: China; Cultural Revolution; Communism; educational function.

Farine, A. La politique de la langue et de 1'enseignement au Québec. pp. 42-50.

Mots-clés: Québec; politique du language; français; anglais.

Keywords: Québec; language policy; French; English.

Kehoe, M. Language and politics in developing areas. pp. 51-58

Keywords: Ethiopia; Korea; second language education; English; politics.

Gulutsan, M. National identity, politics and education in Romania. pp. 59-78

Keywords: Romania; public education; Nationalism; educational reform.

Narang, H. L. A bibliography of Canadian theses on comparative and international education. pp. 79--86.

Keywords: Canada; Master theses 1934 - 1969. Doctoral dissertations: 1917- 1969

\section{Book Reviews}

Bremer, J. \& Moschzisker, M. (1971). The school without walls: Philadelphia's parkway program. Holt, Rinehart and Winston, Inc. Reviewed by Goodenough, T. p.87

\section{Volume 1, number 2, December 1972}

Kidd, J. R. Other streets in the global village. pp. 4-15

Keywords: UNESCO; CSSE; comparative education; educational renovation.

Halls, W. D. Trends in upper academic secondary education in Europe. pp. 16-28 Keywords: secondary education; curriculum; elitist education; teaching method; evaluation; European countries

Ellis, D., Archer, M. \& Mons, F. Les écoles ontariennes au service des francophones. pp. 29-34 
Mots-clés: Ontario; écoles secondaires publiques de langue française; (projet de loi 141); livres scolaires en français; étudiants francophones dans la société anglophone.

Keywords: Ontario; French secondary public schools (Bill 141); French textbooks; Francophone students in an Anglophone society.

Minogue, W. J. D. Distributive justice and foreign university students: A New Zealand view. pp. 35-43

Keywords: New Zeland; educational exchange program; bilingual; biculturalism; foreign university students.

Miller, R. M. Alternatives for educational development: Case studies or practical applications. pp. $44-55$

Keywords: Educational alternative; non-formal education; program innovation; developing countries

Dahlie, J. Learning on the frontier: Scandinavian immigrants and education in Western Canada. pp. 56-66

Keywords: Western Canada; Scandinavian immigrants; adjustment; immigrant education.

\section{Book Reviews}

Fraser, S. E. (1972). Sex, school and society: International perspectives. Nashville and London: George Peabody College for Teachers and Aurora Publishers, Inc. Reviewed by Brady, D. B. p. 70

Blackington III, F. H. \& Patterson, R. S. (Ed.). (1968). Society, school and the professional educator, A book of readings. New York: Holt, Rinehart \& Winston. Reviewed by Ray, D. p. 74

Tomiak, J. J. \& Abbot, N. (1972). The Soviet Union. Devon, England: David and Charles Ltd. Reviewed by Skinner, A. F. p.75

Marcel de Grandpré (1972). Documents d'éducation comparée, 1. Articles sur les méthodes 2. Traités généraux 3. Travaux de recherche. Montréal: La Librairie de l'Université de Montréal. Reviewed by A. Farine. p. 77.

\section{Volume 2, number 1, June 1973}

Wilson, D. N. University of Canada North: Promise for an alternative university structure. pp. 3-14

Keywords: Canada; Native education; university structure; culture change.

Cowen, R. A query concerning developments within and the responsibilities of comparative education. pp. 15-29 
Keywords: society and education; educational reform; comparative education; higher education.

Gouveia, J. L. L'éducation en Afrique du Centre: une prospection de la situation. pp. $30-46$

Mots-clés: Afrique subsaharienne; méthodes d'enseignement traditionnel avant la colonisation; écoles coraniques; enseignement colonial; éducation et objectifs nationaux.

Keywords: Sub-Saharan Africa; traditional education methods before colonisation; Coranic schools; colonial education; education and national objectives.

Holland, J. W. A reappearance of national and provincial educational policy styles. pp. 47-66

Keywords: nation-building; efficiency concept; educational policy; equity

Elias, J. L. Adult literacy education in Brazil, 1961-1964: Metodo Paulo Freire. pp. $67-84$

Keywords: literacy education; Metodo Paulo Freire; Popular Culture Movement; Brazil

Pilkington, G. The foundations of higher education in Japan: A key to understanding current issues? pp. 85-99

Keywords: Japan; educational system; educational reform; higher education.

Magnuson, R. Teaching comparative education: The use of literary sources. pp. 100-107

Keywords: literature; comparative education

\section{Book Reviews}

Perkins, J. A. \& Israel, B. B. (Ed.). (1972). Higher education: From autonomy to systems. New York: International Council for Educational Development. Reviewed by Sheffield, E. F. p. 110

Learning to be: The world of education today and tomorrow. (1972). Report of the International Commission on the Development of Education. Paris and London: UNESCO and Harrap. Reviewed by Thomas, A. M. p. 113.

\section{Volume 2, number 2, December 1973}

Guest Editorial: Skinner, A. F. Insight and outlook. pp. 3-11

King, E. J. Comparative studies in the education of teachers. pp. 12-22 
Keywords: educational system; cross-cultural comparison; teacher training;

Entwistle, H. Comparative studies in the education of teachers: Some pedagogical problems. pp. 23-29 (Response to E. J. King's article)

Delchet, R. Le rôle et la place de 1'éducation comparée dans la formation des enseignants. pp. 30-45

Mots-clés: International, France; influence de l'éducation comparée sur la formation des enseignants; perspectives de l'enseignement des sciences.

Keywords: International, France; compartive education's influence over teacher training; education science perspectives.

Grandpré, M. Point de vue Québécois. pp. 46-53 (Response -in support- to R. Delchet's article)

Mots-clés: Québec; éducation comparée et la formation des enseignants. le rapport Parent; la réforme du système scolaire; rôles de l'éducation comparée.

Keywords: Québec. Comparative education and teacher training. Parent's report and school system reform; comparative education roles.

Brickman, W. Comparative and international teacher education in historical perspective. pp. 54-76

Keywords: Ancient and modern teacher education; comparative studies; historical perspectivesreview; higher education.

Magnuson, R. Nationalism in the historical development of western education. pp. 77-82 (Response to W. Brickman's article)

Keywords: Internationalism through education; medieval education; formal education's role in nation-building and in economic development.

Couch, V. J. Comparative education: Its relevance for teacher education in Australia. pp. 83-93

Keywords: Australia; teacher education; comparative education.

Gillett, M. Closer to the centre. pp. 94-98 (Response to V. Couch's article)

Hellyer, M. J. A practical experiment in international education: A report of a short-term academic exchange. pp. 99-101

\section{Book Reviews}

King, E. J. (1973). Other schools and ours: Comparative studies for today ( $4^{\text {th }}$ ed.) London, Toronto etc.: Holt, Rinehart and Winston.

Boyd, W. \& King, E. J. (1972). The history of western education (10 ${ }^{\text {th }}$ ed)

London: A. \& C. Black. Jointly Reviewed by Skinner, A. F. p. 102

Morrison, T. \& Burton, A. (Ed.). (1973). Options: Reforms and alternatives for Canadian education. Toronto: Holt, Rinehart and Winston of Canada Ltd. Reviewed by Brady, D. B. p. 108 


\section{Volume 3, number 1, June 1974}

Editorial: Ray, D. Comparative and international education in Canada, 1973. p. 1-3

Kong, S. L. China educates the people-ocean. pp. 4-16

Keywords: China; Mao's education thought; socialism; Cultural Revolution; higher education; mass education

Stamp, R. M. Canadian universities and Canadian identity. pp. 17-33

Keywords: nationalist movement; Canadian higher education; national identity

Wilson, D. N. A comparative analysis of four models in non-formal education: Denmark, Israel, Malawi and Côte d'Ivoire. pp. 34-51

Keywords: Denmark; Israel; Malawi; Côte d'Ivoire; rural non-formal education; educational system; comparative studies;

Lipkin, J. P. The "academic tilt" in Quebec post-secondary education. pp. 53-60

Keywords: higher education; social equality; drop-out rates; educational opportunities expansion

Wilson, J. D. Charles Duncombe as educational reformer: A case study of U.S. influence on Canadian education. pp. 61-75

Keywords: USA; Canada; Charles Duncombe; educational reform; American influence; Canadian educational system

Dow, M. R. Consequences of the Cultural Revolution on China's educational system. pp. 76-82

Keywords: China; Cultural Revolution; social and moral codes; Chinese education; educational reform

\section{Book Reviews}

McLeod, T. H. (Ed.). (1973). Post-secondary education in a technological society. Montreal: McGill-Queen's University Press. Reviewed by Holland, J. W. p. 83

Bereday, G. Z. F. (1973). Universities for all: International perspectives on mass higher education. San Francisco, Washington, London: Jossey-Bass Publishers. Reviewed by Cowen, R. p. 86

Grandpré, M. (1973). La coéducation dans les écoles de 45 pays. Sherbrooke: Editions Paulines. Reviewed by Gagné, J. R. p. 90

Bell, R., Fowler, G. \& Little, K. (Ed.). (1973). Education in Great Britain and Ireland: A source book. London \& Boston: Routledge and Kegan Paul in association with The open University Press. Reviewed by Skinner, A. F. p. 92

Butcher, H. J. \& Pont, H. B. (Ed.). (1973). Educational research in Britain. London: University of London Press, Ltd. Reviewed by Robinson, G. 


\section{p. 95}

Lauwerys, J. \& Tayar, G. (Ed.). (1973). Education at home and abroad. London: Routledge and Kegan Paul. Reviewed by Rey, D. p. 99

Gagné, J. R. (1972). Personalizing the educational experience and the HallDennis report. Ann Arbor: University of Michigan. Reviewed by Bancroft, G. W. p. 101

Patterson, R. S., Chalmers, J. W. \& Friesen, J. W. (Ed.). (1974). Profiles of Canadian educators. Toronto: D. C. Health, Canada Ltd. Reviewed by Brehaut, W. p. 104.

\section{Volume 3, number 2, December 1974}

Ray, D. The Canadian educational take-off: An assessment, some comparisons, and conjectures. pp. 1-23

Keywords: Canada; educational reform; educational equality; educational policy.

Gleason, T. P., Rankine, F. C. \& Roy, H. Apparition d'une troisième culture; manifestation d'une vue d'ensemble du monde chez les étudiants sousgradés francophones et anglophones au Nouveau Brunswick, Canada. 1971-73. pp. 24-38

Mots-clés: Nouveau-Brunswick, Canada; étudiants de la licence; perceptions des étudiants francophone et anglophone sur l'enseignement supérieur; rajustement social.

Keywords: New-Brunswick, Canada; Under-graduate; Francophone and Anglophone students' perceptionn on higher education; social adjustments.

Wilson, D. N. The interaction of urbanization and education in three African states: Nigeria, Zaïre and Malawi. pp. 39-73

Keywords: Nigeria, Zaïre and Malaw; educational system planning; urbanisation; institutional transfer; developing countries

Drysdale, R. S. Education for rural society in transition: the case of Peru. pp. 7498

Keywords: rural education; social structure; educational change; Peru

Price, J. A. An ethnographic approach to U.S. and Canadian Indian education. pp. 99-115.

Keywords: enculturation; Western civilization; Indian schools; Indian culture

Mallea, J. R. Changing concepts of merit in modern Japan. pp. 116-133

Keywords: Japan; society modernization; merit ideology; ShintoConfucian orthodoxy 
Milburn, D. Observations on “Going British Primary”. pp. 134-140

Keywords: Britain; educational movement; child-centred education.

\section{Book Reviews}

Edwards, R., Holmes, B. \& Graaff, J. V. (Ed.). (1973). Relevant methods in comparative education. Hamburg: UNESCO Institute for Education. Reviewed by Ray, D. p. 141.

Paulston, R. G. (1974). Folk schools in social change: A partisan guide to the international literature. Pittsburgh: University Center for International Studies, University of Pittsburgh. Reviewed by Kulich, J. p. 144.

Plourde, M. Revue de l'Association Canadienne d'Education de langue Français (ACELF). Reviewed by Farine, A. p. 146.

\section{Volume 4, number 1, June 1975}

Eedle, J. Education for the seventies: "A ministerial statement". pp. 1-18

Keywords: national identity; educational system; education quality; practical work

Drysdale, R. S. Primary schooling in Columbia: An overview and case study. pp. $19-41$

Keywords: Columbia; primary education; drop-out rate; family situation.

Farine, A. Attitudes de travail des diplômes universitaires. pp. 42-54

Mots-clés: Préparation au travail; emploiement; études supérieures, politique de l'enseignement.

Keywords: job preparation; employment; higher education; educational policy.

Lam, Y. J. Educational technology in different socio-cultural contexts. pp. 55-68

Keywords: HongKong; Canada; educational technology; professional training; financial support; educational philosophy.

Malikail, J. S. The public school system in India. pp. 69-88

Keywords: India; public school; educational system; historical development.

Mallea, J. R. The public purse and the private pocket: The fiscal crisis in Japanese higher education. pp. 89-98.

Keywords:Japan; higher education; scholarship; loan system.

\section{Book Reviews}

Katz, J. (1974). Education in Canada. Vancouver: Douglas, David \& Charles. Reviewed by Purdy, J. D. p. 99 
Trotter, B. et al. (1974). Planning for planning-relationships between universities and governments: Guidelines to process. Ottawa: Association of Universities and Colleges of Canada. Reviewed by Stevenson, H. p. 100

Boudon, R. (1974). Education, opportunity and social inquality: Changing prospects in Western society. Toronto: John Wiley. Reviewed by Ray, D. W. p. 102

King, E. J., Moor, C. H. \& Mundy, J. A. (1974). Post compulsory education: A new analysis in Western Europe. London: Sage. Reviewed by Ray, D. W. p. 104

Bell, R. \& Grant, N. (1974). A mythology of British education. London: Panther books.

King, R. (1973). School organization and pupil involvement. London: Routledge and Kegan Paul.

Taylor, P. H., Reid, W. A. \& Holley, B. J. (1974). The English sixth form: A case study in curriculum research. London: Routledge and Kegan Paul.

Jointly Reviewed by Hamilton, W. B. p.107

Schiefelbein, E. \& Davis, R. G. (1974). Development of educational planning models and application on the Chilean school reform. Lexington, Mass: Lexington Books, D. C. Heath and Company. Reviewed by Drysdale, R. S. p. 110

Milburn, G. \& Herbert, J. (Ed.). (1975). National consciousness and the curriculum: The Canadian case. Toronto: Ontario Institute fro Studies in Education. Reviewed by Westmacott, M. p.112

Brembeck, C. S. \& Hills, W. H. (Ed.). (1973). Cultural challenges to education. Toronto: D. C. Heath and Co. Reviewed by Blackbird, W. p.114

Education on the move. (1975). Extracts from Background Papers prepared for the Report of the International Commission on the Development of Education. Toronto: The Ontario Institute for Studies in Education; Paris: The UNESCO Press. Reviewed by Katz, J. p.115

\section{Volume 4, number 2, December 1975}

Editorial

Mackinnon, A. R. Canadian programs in Third World education development: An overview of Canadian programs. pp. 1-16

Keywords: Canada; educational program; developing countries; school functions.

Simpson, D. G. Education: A policy for serving the most children. pp. 17-22

Keywords: IDRC (the International Development Research Centre); children education 
Patterson, M. E., Hoffman, P., Christie, J. \& Pollock, D. Canadian university service overseas (CUSO): Its experience in education. pp. 25-32

Keywords: CUSO; developing countries; Western schooling

Kidd, J. R. Development means human development: The International Council for Adult Education. pp. 35-48

Keywords: human development program; adult education; international co-operation.

Butcher, R. An experiment in cross-cultural learning. pp. 51-57

Keywords: Third World countries; Canada; cross-cultural learning.

Stabler, E. Faculties of Education and the Third World. pp. 59-70

Keywords: Developing countries; overseas experience; faculty of education.

Barker, R. M. "Be an enthusiast". pp. 73-85

Keywords: Developing countries; Canada; educational co-operation; teacher organizaiton.

Burke, M. E. Communication, co-ordination, co-operation: Imperatives for the bilateral dimension of Canadian educational assistance to the Third World. pp. 87-102.

Keywords: Developing countries; CUSO; CIDA; educational participation; assistance models.

\section{Volume 5, number 1, June 1976}

Farine, A. \& Knowles, R. Le secteur de 1'enseignement au Canada. pp. 1-12

Mots-clés: Canada; éducation; emploiement; qualification;formation des enseignants.

Keywords: Canada; education; employment; qualification; teacher training;

Moreaux, C. Politique et savoir; remarques pour une analyse des mouvements sociaux. pp. 14-26.

Keywords: student movements; pedagogy reforms; professor/student relationship.

Tsurumi, E. P. Attempting to create a colonial mentality: Japanese elementary education in Taiwan, 1895-1945. pp. 28-45.

Keywords: Taiwan; colonial education; assimilation; the educational policy; Japanese elementary education.

Bergen, J. J. The preparation and selection of educational administrators in West Germany. pp. 46-68.

Keywords: West-Germany; educational administration; administrator preparation and selection; 
Jacob, J. The role of the school in Latin American rural-to-urban migration. pp. 70-93.

Keywords: Latin America; migration theory; rural-to-urban migration; schooling and migration.

Maleche, A. interrelationships between economic and educational change in Kenya. pp. 94-107.

Keywords: Kenya; educational reform; economic and education relation.

DeCora, P. J. \& Austen, G. J. Perspectives on the South Pacific: An island view of curriculum development. pp. 108-119.

Keywords: The South Pacific; curriculum development; cultural environment influence.

\section{Book Reviews}

Kerekes, A. Z. \& Collins, I. J. (Ed.). (1975). The egalitarian option: Perspectives on Canadian education. The Compass Associates. Reviewed by Campbell, M.B. p. 120.

Faris, R. The passionate educators. Peter Martin Associates Ltd Reviewed by Hay, G. p.123.

Roby-Kidd, J.(1974). Whilst time is burning. Ottawa: International Development Research Centre. Reviewed by Zachariah, M. p.124.

Husén, T. (1974). The learning society. Agincourt, Ontario: Methuen. Reviewed by Ray, D. p.126.

Randall, M. (1974). Cuban women now: Interviews with Cuban women. Toronto: Canadian Women's Educational Press. Reviewed by Ayim, M. p.128.

Davitt, P. et. al. (1974). Never done - Three centuries of women's work in Canada. Toronto: The Canadian Women's Educational Press. Reviewed by Ayim, M. p.130.

Acton, J., Goldsmith, P. \& Shepard, B. (Ed.). (1974). Women at work - Ontario, 1850-1930. Reviewed by Ayim, M. p.131.

Martin, W. B. W. (1976). The negotiated order of the school. Toronto: Macmillan of Canada. Reviewed by Sanders, J. T. p.134.

\section{Volume 5, number 2, December 1976}

Morris, L. The politics of education and language in Quebec: A comparative perspective. pp. 1-36

Keywords: Quebec; ethnicity; language in education; French-speaking Canadians; decentralization.

Pilkington, G. Higher education in Quebec: A product of evolution and revolution. pp. 38-70. 
Keywords: Quebec; higher education; cultural socio-political setting; legislation; financial issue.

Cornell, M. L. The development of education for women in Kuwait. pp. 72-83.

Keywords: Kuwait; Muslim; women education; educated women social status.

Malikail, J. S. State policies on moral and religious education in India, 18581967. pp. 84-106.

Keywords: moral education; religious education; state policy; India

Bacchus, M. K. Some observations on social structure and craft training in economically less developed countries. pp. 108-123.

Keywords: technical education; academic education; curriculum reform; developing countries

\section{Book Reviews}

Non-formal education: Review of a trilogy. Reviewed by Shute, J. C. M. p.124-. Hearnden, A. (1976). Education, culture and politics in West Germany. Oxford: Pergamon Press. Reviewed by Bergen, J. J. p.127.

Shneidman, N. N. (1974). Literature and ideology in Soviet education. Lexington, Mass.:Lexington Books, D. C. Health \& Co. Reviewed by Pospielovsky, D. p. 130.

Verma, G. K. \& Bagley, C. (Eds.). (1975). Race and education across cultures. London: Heinemann. Reviewed by Ray, D. p.133.

King, E. J., Moor, C. H. \& Mundy, J. A. (1975). Post compulsory education: The way ahead. London and Beverley Hills: Sage. Reviewed by Ray, D. p.137.

\section{Volume 6, number 1, June 1977}

Denis, A. B. Nationalism and multiculturalism in Quebec. pp. 1-13.

Keywords: Quebec; ethnic relations; nationalism; multiculturalism; educational structure.

Covert, J. R. The use of post-literate technology in a pre-literate culture: Examples and implications. pp. 15-32.

Keywords: pre-literate learning style; post-literate teaching technique; formal education; non-formal education; informal education

Lam, Y. J. A path analysis of cultures, school structures and educational technology. pp. 35-50.

Keywords: educational culture; school structures; educational technology

Lawson, R. F. Democratic progress in West German education. pp. 53-63. 
Keywords: West Germany; educational function; educational system; educational reform.

Mehmet, O. Educational inequality and dependence on foreign manpower in Liberia. pp. 65-78.

Keywords: Liberia; educational inequality; economic dependence; educational opportunity.

\section{Book Reviews}

Crean, S. M. (1976). Who's afraid of Canadian culture. Toronto: The General Publishing Group. Reviewed by Lawr, D. p.80

Carlton, R.A., Colley, L. A. \& MacKinnon, N. J. (Eds.). (1977). Education, change, and society: A sociology of Canadian education. Toronto: Gage Educational Publishing Ltd. Reviewed by Desroches, J. p.83

Harris, R. S. (1976). A history of higher education in Canada 1663-1960. Toronto: University of Toronto Press. Reviewed by Purdy, J. D. p.85.

Matheson, G. (Ed.). (1976). Women in the Canadian mosaic. Toronto: Peter Martin Associates Limited. Reviewed by Ayim, M. p.87.

Anderson, G. M. \& Higgs, D. (1976). A future to inherit: The Portuguese community in Canada. Toronto: McClelland \& Stewart. Reviewed by Costa, D.\& Kushnier, Y. p.90.

Radecki, H. \& Heydenkorn, B. (1976). A member of a distinguished family: The Polish group in Canada. Toronto: McClelland \& Stewart. Reviewed by Struzik, E. p.92.

Kessen, W. (Ed.) (1975). Childhood in China. New Haven: Yale University Press. Reviewed by Semotiuk, D. p.94.

Kobayashi, T. (1976). Society, schools and progress in Japan. Toronto: Pergamon Press. Reviewed by . Mallea, J. R. p.96.

\section{Volume 6, number 2, December 1976}

A Report from the President

Podmore, C. Private schools - An international comparison. pp. 8-33

Keywords: Canada; private school; modernization; cross-national comparison.

Thomson, C. The emergence of Native American education at the University of Lethbridge. pp. 34-48.

Keywords: Native American education; Native American teacher training; racism; Canadian university.

Hegmann, F. Fundamental issues and present trends in West-German secondary education. pp. 49-59. 
Keywords: West Germany; educational reform; secondary education; different school systems.

Bazargan, F. A survey of educational problems in Iran. pp. 60-74.

Keywords: Iran; educational system development; illiteracy rate; secondary education inefficiency; Iran

Lindsey, J. K. Social class and primary school age in Bombay: The role of education in the transition to capitalism. pp. 75-97

Keywords: Bombay, India; social class; function of education; capitalism; social mobility.

\section{Book Reviews}

Dore, R.(1976). The diploma disease: Education, qualification and development. Berkeley: University of California. Reviewed by Tsurumi, E. P. p.98-.

Jones, P. E. (1971). Comparative education: Purpose and method. St. Lucia, Australia: University of Queensland Press. Reviewed by De Grandpré, M. p.102.

Lortie, D. C. (1975). School-teacher, A sociological study. Chicago: The University of Chicago Press.

Chapoulie, J. Sur l'analyse sociologique des groupes professionnels. Revue française de Sociologie, XIV, 1973, pp. 86.

Chapoulie, J. Le corps professoral dans la structure de classe. Revue française de Sociologie, XV, 1974, pp. 155-200.

Jointly Reviewed by Lessard, C. p.103.

Stevenson, H. A. \& Wilson, J. D. (Eds.). (1977). Perspectives on contemporary Canadian education. London, Ont.: Alexander, Blake Associates. Reviwed by Malikail, J. p.109,

Thompson, K.W. \& Fogel, B. R.(1976). Higher education and social change, Vol. 1. New York: Praeger.

Thompson, K.W. \& Fogel, B. R.(1977). Higher education and social change, Vol. 2. New York: Praeger.

Jointly Reviewed by Naughton, P. W. p.112.

Tuckman, H. (1976). Publication, teaching, and the academic reward structure. Toronto: Lexington Books, D. C. Health Canada. Reviewed by Emerson, G. J. p.114.

Walker, W.G., Mumford, J.E. \& Steel, C. A glossary of educational terms: Usage in five English-speaking countries. St. Lucia, Australia: University of Queensland Press. Reviewed by De Grandpré, M. p.116.

Yinger, J. M., Ikeda, K., Laycock, F., \& Cutler, S. J. (1977). Middle start. New York: Cambridge University Press. Reviewed by Sanders, J. T. p.117. 
Kattackal, J. A. Education in India's Five Year Plans: A historical review (195176) and critical appraisal. pp. 526

Keywords: India; educational plan; secondary and higher education

Khoi, L. T. Les programmes d' éducation anti-drogue en Asie du Sud-Est. pp. 2736.

Mots-clés: Asie du Sud-Est; innovations pédagogiques; enseignement contre la drogue; modèle psycho-social ; média.

Keywords: South-East Asia; educational innovation; anti-drug education; psycho-social model; mass-media.

O’Bryne, V. L'enseignment des langues des groupes ethniques en Australie. pp. 37-41.

Keywords: Australia; ethnic language education; immigrants; multicultural community; difficulties.

Gillett, M. The majority minority: Women in Canadian universities. pp. 42-50.

Keywords: Women's academic and professional status; minority situation; problems; solutions; Canadian universities.

Leduc, C. Les orientations des femmes à l'Université de Montréal en 1949-50 et en 1974-75. pp. 51-58.

Mots-clés: Université de Montréal; enrôlement des femmes; inégalité croissante; dans enseignement supérieur.

Keywords: University of Montreal; female enrolments; increasing disparity; higher education; .

Schiefelbein, E. \& Farrell, J. Social and pedagogical factors influencing survival in the schools of Chile. pp. 59-87.

Keywords: Chile; equality in education; national education policy; educational reform.

\section{Book Reviews}

Baker, L. (1976). I'm Radcliffe! Fly me! The seven sisters and the failure of women's education. New York: Macmillan. Reviewed by Ayim, M. p.88.

Education Compare. Reviewed by Grandfré, M. p.90

Entwinstle, H. (1977). Class, culture and education. London: Methuen and Co. LTD. Reviewed by Hamalian, A. p.91

Hawes, H., Aarons,A., Craft, J. \& Hawes, C. (1978). Curriculum and reality in African primary schools. Longman:London. Reviewed by Sachsenmeier, P. p.93 
Johnston, C. (1976). McMaster university, The Toronto Years, Vol.1, Toronto. Toronto: The University of Toronto Press. Reviewed by Purdy, J.D. p.97.

Kloskowaska, A. \& Martinotti, G. (Ed.). (1977). Education in a changing society. Beverly Hills: Sage Publicaions. Reviewed by Duchastel, J. p.98

Khoi, L. T. (1978). Jeunesse exploitée, jeunesse perdue? Paris: Presses universitaires de France, collection "Sociologie d'aujourd'hui". Reviewed by Joly, R. p.102

Wilfred, B.W., Macdonell, M. \& Macdonell, A.J. (1977). Canadian education: A sociological analysis. Scarborough: Prentice-Hall. Reviewed by Emerson, G. p.106

Parsons, T. \& Platt, G. (1973). The American university. Cambridge: Harvard University Press.

Touraine, A. (1972). Université et société aux États-Unis. Paris: Éditions du Seuil. Jointly Reviewed by Lessard, C. p.107

Recherche, pédagogie et culture. Paris: AUDECAM. Reviewed by Grandpré, M. p. 110

Ritterbrand, P. (1978). Education, employment, and migration: Israel in comparative perspective. Cambridge: Cambridge University Press. Reviewed by Joffe, A. p.111.

\section{Volume 7, number 2, December 1978}

Pooley, J. C. Comparative physical education and sport programmes in Canadian universities: An analysis. pp. 5-16

Keywords: comparative physical education; professional qualifications; course content; course preparation; Canadian universities

Percival, S. G. \& Shute, J. C. M. A study of teacher preparation for overseas work. pp. 17-27.

Keywords: Canada; teacher satisfaction; overseas assignment preparation; international service; profession training; Canada

Wilson, D. Universal primary education in Nigeria: An appraisal of plan implementation. pp. 28-52.

Keywords: Nigeria; primary education; policy implementation; problems

Debeauvais, M. Le rôle des organisations internationales dans l' évolution de l'éducation comparée. pp. 53-63.

Mots-clés: Organisations internationales; éducation comparée; modèle de société de consommation; réformes radicales de l'enseignement.

Keywords: international organizations; comparative education; consumer-society model; radical educational reforms. 
Lindsey, J. K. School, state, caste, and class in Bombay. pp. 64-80

Keywords: role of education; transition; traditional society; capitalist society; social class; caste structure; Bombay

Kashti, Y. The residential setting and its influence on changes in attitudes and values among disadvantaged youths. pp. 81-94.

Keywords: Israel; residential setting; conflicting orientation decreasing; culturally disadvantaged adolescents.

\section{Comment}

Grandpré, M. Après 25 ans d' éducation comparée. pp. 95-99

\section{Book Reviews}

Philip, G., Kelly, A. \& Kelly, G. P. (1978). Education and colonialism. New York: Longman. Reviewed by Ghosh, R. p.100.

Goble, N. \& Porter, J. F. (1977). L' évolution du rôle du maître: Perspectives internationales. Paris: UNESCO, Bureau International d'Éducation. Reviewed by Henriquez, S. p.101.

Nyström, A. (1978). French as a foreign language. Stockholm: Almqvist \& Wiksell International.

Reviewed by D'anglejan A. p.105.

Price, R. F. (1977). Marx and education in Russia and China. London: Croom Helm Ltd. Reviewed by Ruud, C.A. p.106.

\section{Volume 8, number 1, 1979}

Livingstone, D. W. The capitalist world economy and the limits of educational reform. pp. 5-26

Keywords: educational structures and practices; capitalist world system; societal context; relations of schooling; Canada; Brazil

Hegmann, F. Teachers, students and parents in West-German education. pp. 27-40 Keywords: teacher training reform; political influence; universities overenrolment; psychological problems; secondary students; West-Germany

Farine, A. La formation professionnelle en France et en Allemagne de l'ouest. pp. 41-47

Mots-clés: France; Allemagne de l'Ouest; système d'enseignement; relation entre l'enseignement et le travail.

Keywords: educational systems; relationship between education and labour; France; West-Germany 
McKenna, M. O. The influence of R.S. Peters on the place of Philosophy of Education in preservice teacher preparation programmes in the United Kingdom. pp. 48-61

Keywords: U.K.; Philosophy of Education; pre-service teacher program; R.S. Peter's "new" concept; integrated "thematic" approach.

Radcliffe, D. Sarvodaya and the Western world. pp. 62-74

Keywords: Sarvodaya Shramandana Movement; non-formal education; application to western societies; Sri Lanka

\section{Book Reviews}

Combs, A. W. (1979). Myths in education. Boston: Allyn \& Bacon Inc. Reviewed by Emerson, G. p.75-76

Grant, C.A. (Ed.). (1978). Community participation in education. Toronto: Allyn \& Bacon. Reviewed by Radcliffe, D. p.76-78

Kozol, J. (1978). Children of the revolution: A Yankee teacher in the Cuban schools. New York: Delacorte Press. Reviewed by Ghosh, R. p.78-79

Troup, F. (1976). Forbidden pastures: Education under apartheid. London: International Defence and Aid Fund for Southern Africa. Reviewed by Laferrière M. p.80-82.

\section{Volume 8, number 2, 1979}

Kong, S. L. Education in Asia --- Introduction. pp. 6-13.

Hayhoe, R. Written language reform and the modernisation of the curriculum: A comparative study of China, Japan and Turkey. pp. 14-33.

Keywords: China; Japan; Turkey; written language reform; curriculum modernisation.

Price, R. F. Educating successors to which revolution in China. pp. 34-46.

Keywords: China, Mao Zedong; democracy; proletarian socialist movement; mass education; class distinctions.

Butler, S. R. \& Sheean, P. J. Changes in Chinese education since the death of Mao Zedong. pp. 47-57.

Keywords: China; teachers' status; curriculum reform; education and productive labour.

Kidd, J. R. Adult learning programs in India and China. pp. 58-82

Keywords: India; China; non-formal education; cultural determinant; ideology; national decision -making.

Bacchus, M. K. Structural transformation as a pre-requisite for the success of nonformal education programmes in economically less developed countries. pp. 83-91. 
Keywords: non-formal education; reward system transformation; the Third World countries

Quang-Nam, T. Éducation et travail productif au Vietnam. pp. 92-99.

Mots-clés: Vietnam; modèle moitié étude - moitié apprentissage; révolution de la production; révolution scientifique, technologique; idéologique et culturelle.

Keywords:Vietnam; half study-half work model; production revolution; scientific, technological revolution; ideological, cultural revolution.

Naughton, P. K. Some comparisons of higher education in Vietnam. pp. 100-116.

Keywords: Vietnam; higher education; French colonial system; Chinese colonial system; comparison.

Wickramasinghe, S. \& Radcliffe, D. Women and education in South Asia. pp. 117-125.

Keywords: Sri Lanka; South Asia; women's education; religious and cultural influence.

\section{Book Reviews}

D’Oyley, V. \& Murray, R. (Ed.). (1979). Development and disillusion in Third World education with emphasis on Jamacia. Toronto: O.I.S.E. Reviewed by Dahlie, J. p.126

Jayasuriya, J. E. (1978). Curriculum innovation through population education. Combo, Sri Lanka: Associated Educational Publishers.

Population education. (1978). Population Profiles No. 11. New York: UNFPA

Population facts at hand. (1979). New York: UNFPA

Jointly Reviewed by Radcliffe, D. p.127

Kwong, J. (1979). Chinese education in transition: Prelude to the cultural revolution. Montreal: McGill-Queen's University Press. Reviewed by Kong, S. L. p.129

Khôi, L. T. (1978). Socilaisme et développement au Vietnam. Paris: Presses Universitaires de France, I.E.D.E.S., Collection Tiers Monde. Reviewed by Mounivongs, K. p.130

Malassis, L. (1979). The rural world: Education and development. Paris: UNESCO. Reviewed by Sugunasiri, S. p.132

Sarup, M. (1978). Marxism and education. London: Routledge \& Kegan, Paul. Reviewed by O'Leary, P. T. p.134.

\section{Volume 9, number 1, 1980}

Churchill, S. International education and education on human rights: The Canadian experience. pp. 6-32. 
Keywords: Canada; human rights education; international education.

Lessard, C. The Montreal school reorganization process: Why and why not? pp. $33-47$

Keywords: Montreal; politics change on school; Quebec evolution; francophone society pluralization.

Willke, I. Bilingual education: The schooling of second-generation children of immigrants. pp. 48-61.

Keywords: Germany; mother tongue maintenance; multi-cultural society; bilingual education; society integration

Turcotte, D. Éducation en langue en Côte d'lvoire. pp. 62-72.

Mots-clés: Côte d'Ivoire; intégration nationale; réformes de l'enseignement; enseignement des langues.

Keywords: Ivory Coast; national integration; educational reforms; language education.

Nicoll, P. Cultural and education equality: The ambivalence of multicultural education in Australia. pp. 73-80.

Keywords: Australia; multicultural education; educational equality.

Bernstein-Tarrow, N. The education of Arab children under Israeli administration. pp. 81-94.

Keywords: Israel; Arab Communities; education of Arab children; pluralistic education policy; society changes.

Balicki, C. \& Iram, Y. Vocational education in Switzerland and Israel: A comparative analysis. pp. 95-105.

Keywords: Switzerland; Israel; vocational education; different training systems; apprenticeship.

\section{Book Reviews}

Archer, M. S. (1979). Social origins of educational systems. London and Beverly Hills: SAGE Publications Ltd. Reviewed by Joffe, A. p.106

Bernard, P., Demers, A., Grenier, D. \& Renaud, J. (1979). L'évolution de la situation socio-économique des francophones et des non-francophones au Québec (1971-1978). Québec: Gouvernement du Québec, Office de la langue française, collection Langues et Sociétés. Reviewed by Lessard, C. p. 107

Barrow, R. (1979). The Canadian curriculum: A personal view. London, Ontario: Faculty of Education, University of Western Ontario. Reviewed by Munby, H. p.109

Hoyles, M. (Ed.). (1979). Changing childhood. London: Writers and Readers Publishing Cooperative. Toronto: Pathway Publishers. Reviewed by Radcliffe, D. p.113. 
Colletta, N. J. \& Radcliffe, D. J. Non-formal education: An educological approach. pp. 7-27

Keywords: formal education; non-formal education; informal education; communications theory

Watson, K. Influences and constraints on curriculum development in the third world. pp. 28-42

Keywords: Malaysia; curriculum reforms; science education; educational legacy

Cuttance, P. The influence of schooling on student academic outcomes: A critical assessment of findings produced in the neo-classical paradigm of schooling effects research. pp. 43-70

Keywords: schooling effects on academic performance; neo-classical paradigm; institutional paradigm

Raggatt, P. Universities, urban schools and curriculum innovations. pp. 71-87.

Keywords: Boston; collaboration between universities and schools; staff development; curriculum design.

\section{Notes and Reports}

Heyneman, S. Instructions in the mother tongue: The question of logistics. pp. 8894.

Keywords: East African country; mother tongue education; logistical feasibility; primary school.

Benavent, J. A. The lower secondary school and in particular its curriculum: The Spanish case. pp. 95-100.

\section{Book Reviews}

Zimmer, A. \& Zimmer, F. (1978). Visual literacy in communication: Designing for development. Amersham, U.K.: Hulton Educational Publications Ltd.

Thomas, F.J. \& Kondo, A.S. (1978). Towards scientific literacy. Amersham, U.K.: Hulton Educational Publications Ltd. Jointly Reviewed by Cookson, P.S. p.101

Paulston, R.G. er al. (1980). Other dreams, other schools: Folk colleges in social and ethnic movements. Pittsburgh: Univeristy Center for International Studies, University of Pittsburgh. Reviewed by Kulich, J. p.103

Farquhar, R.H. \& Housego, I.E. (Ed.). (1980). Canadian and comparative educational administration. Vancouver: Centre for Continuing Education, UBC. Reviewed by Allison, D. J. p.106. 


\section{Volume 10, number 1, 1981}

Kay, W. Problems with the Problem Approach. pp.5-20

Keywords: Brian Holmes's Problem approach; social engineering

Campbell, M. B. The Interplay of Multicultural Education and Comparative Studies in Education old Orders or new. pp. 21-31

Keywords: comparative studies; education; multicultural education; cultural pluralism; divergent unities

Burgess, D. A. The IIe-Perrot School Question: A Quebec Case Study. pp. 32-41

Keywords: student enrollment; school closure; school boards; protestant and catholic schools; Quebec education

Malikail, J. S. Teacher Education in France: Tradition and change. pp. 42-60

Keywords: France; education; hierarchy of education; practical teaching; process of certification

\section{Notes and Reports}

Ray, D. Teacher Education in Canada and the UNESCO Recommendation Concerning Education for International Understanding Cooperation and Peace, and Education Relation to Human Rights and Fundamental Freedoms. pp. 61-76

Keywords: teacher education; Canada; international education

\section{Reviews-Recensions}

Lindsey, J. K. Review Essay of Political Conflict and Curriculum Change. p.77-

Cookson, P. S. The World Literacy: Policy, research and Action. For the International Council of Adult education by Margarat Gayfer, budd L. Hall, J. Roby Kidd and Virginia Shrivasava. p. 93

Allen, D. La perception des employeurs des liens qui existent entre la formation et l'employ par Avigdor Farine. p. 95

Luft, M. Education, Social Structure, and Development by Bill Williamson. p.95.

\section{Volume 10, number 2, 1981}

Weis, L. Educational Outcomes and School Process: Theoretical perspectives. pp. 6-20

Keywords: internal workings of the classroom; outcomes of schooling

Newman, R. S. A Fatal History of Agricultural Extension Education. pp. 21-39

Keywords: institutional transfer; agricultural extension education; native culture; china; the USA 
Lam, Y. L. On Organizational External Environment Models: An integrative perspective. pp. 40-47

Keywords: organizational external environments model; cross-cultural comparison; contingency theory; conceptual adequacy; construct validity

Byram, M. Popular Participation and the Mass Media. pp. 48-64

Keywords: popular participation; power; control of resources; participatory research; social reality

\section{Notes and Reports}

Leonard, L. Canadian Studies in American Universities and Schools: Achievements and Problems. pp. 65-72

\section{Reviews-Recensions}

Layne, A. Some Issues in Education for Development: A Review of Education for Development or Underdevelopment? By M. K. Bacchus. p. 73

Carmen Jofre, R. Peru: Reforma educative en una sociedad de clases. (Educational reform in a class society) by Miguel Azcueta. p. 82

Luft, M. Education and Social Change: A photographic study of Peru. By Deborah Barndt. p. 87

Zachariah, M. International Bibliography of Comparative Education. By Philip G. Altbach, Gail P. Kelly and H. Kelly. p. 90.

\section{Volume 11, Number 1, 1982}

Miranda, E. O. Educating Women for Development. pp. 7-22

Keywords: development; education; societal and global development

Turcotte, Denis. Politique, Education et Langue en Polynesie Francaise. pp. 23-32

Keywords: teaching Tahitian, the Polynesian vernacular language; politicized language

Maclure, R. A. UPE and Rural Development in Nigeria. pp. 33-42

Keywords: UPE; university primary education; migration

\section{Notes and Reports}

Elcock, M. the Preparation and Training of Educational Administrators: An International View. pp. 43-54

Keywords: educational administration; West Germany; international intervisitation program

Hayhoe, R. Chinese Universities and the West: Issues and debates in the eighties. pp. 55-66

Keywords: undergraduate curriculum in china; administration; 
Bowd, A. D. Some Trends in Australian Aboriginal Education. pp. 67-72

Keywords: remedial education; supplementary education; instrumental education

\section{Reviews-Recensions}

Hinds, H. E. Jr. Review Essay: If you have been to Mexico lately, did you notice what most Mexicans are reading? Would you believe its comics and photo-novels? pp. 73-79

Bacchus, M. K. Elite vs Mass Considerations in Education for Development: a reply to Layne's Review of education for Development or Underdevelopment? pp. 80-86

Mounivongs, K. Processus de recherché, une approche systematique Andre Ouellet. pp. 86-87.

\section{Volume 11, number 2, 1982}

Gaudreau, J. L'ambigüe notion d'enfant. pp. 5-26.

Mots-clés: enfant; définitions et variantes; habillements; éducation; maturité; différents traitement devant la loi entre garçons et filles.

Keywords: infant/child; definition and variation; clothings; education; maturity; different treatments by the law between boys and girls.

Baksh, i. j. Educational Expansion and Opportunity in Trinidad and Tobago. pp. $27-42$

Keywords: Trinidad; inequality of opportunity; socio-economic status; education.

Laphkas, C. Return Migration: School adjustment of Greek migrant workers' children. pp. 43-55

Keywords: Greece; returning migrants; adjustments to school academic difficulties; linguistic performance

\section{Notes and Reports}

Mitter, W. Teacher Education: Academic Training or practical Orientation. pp. 56-69

Keywords: elementary and secondary teacher education; professionoriented education

Edmonds, E. L. Innovation and International Education. pp. 70-86

Keywords: international education; international curriculum; core curriculum

Campbell, C. Human Resource Development in Saudi Arabia with an Emphasis on Skilled Manpower. pp. 87-102 
Keywords: Saudi Arabia; industrialization; vocational and technical education; trained work force

Statistics Canada. Education Prices Increase Less Rapidly than Consumer Prices. pp. 103-105

\section{Reviews-Recensions}

Miranda, E. O. Open-mindedness and Education William Hare. pp. 106-108

Ray, D. Education in the USSR. Joseph I. Zajda. pp. 109-112

Thai, Quang-Nam. L’Education comparée. Le Thanh Khoi. pp. 112-113.

\section{Volume 12 number 1,1983}

Haddad, W. The World Bank's Education Sector Policy Paper. pp. 11-27

Keywords: education; investment; social and cultural resources; economic development role of education

Ketudat, S. The World Bank and Education: Reflections of a Partner. 28-32

Keywords: human resources; education; development; participation

Wolff, L. World Bank Lending in Education: One view of how it happens. pp. 3339

Keywords: World Bank; national government

Moock, P. R. and Horn, R. Overview of the World Bank's Research on Education. pp. 39-64

Keywords: internal organization of the World Bank; educational research; assessment

Habte, A. Where the World Bank is Going in Education. pp. 65-74

Keywords: cultures; values; education; development; needs

\section{Reviews-Recensions}

Jacob, J. C. Toward a Statement of Equality of Educational Opportunity in Canada: a review of Stations and Callings. pp. 75-85.

\section{Volume 12, number 2, 1983}

Millot, B. Le temps: Lieu de rencontre des économistes et des éducateurs. pp. 713

Mots-clés: Economie et éducateurs; durée des études; nécessités pédagogiques.

Keywords: economics and educators; length of schooling; pedagogical necessities 
Thomas, J. Albania's National Renaissance: Aspirations for Schooling. pp. 14-21

Keywords: Albania National Renaissance; ottoman Turks; cultural and national identity; Catholic Clerks; Istanbul

Burnell, J. The Decline of German Language and Culture in the North American Heartland, 1890-1923. pp. 22-35

Keywords: German settlements; Ontario; Canada; ethnic identity; individuality; collectivity

Mathies, R. J. Evaluation of Voluntary Programs in three African Countries: Perceptions and Concerns of Volunteers. pp. 36-50

Keywords: Voluntary programs; systematic assessment; perceptions

\section{Notes and Reports}

Beauchamp, E. R. Doctoral Dissertations on the History of Canadian Education (1970-1980). pp. 51-54

\section{Reviews--Recensions}

Masemann, V. L. Doing the Ethnography of Schooling: Educational Anthropology in Action by George Spindler. pp. 55-57

Chapman, R. S. Culture and Adult Education: A study of Alberta and Quebec Hayden Roberts. pp. 57-59

Boberg, A. We talked Very Warily: A history of women at McGill. Margaret Gillett. pp. 59-60

Ray, D. The Treatment of the Holocaust in Canadian History and Social Science Textbooks. pp. 60- 61

\section{Volume 13, number 1, 1984}

Kumar, K. Symbols of Development: A study of educational media. pp. 5-18

Keywords: development of education; Canada; television programs; Ontario

Marshall, D. G. Educational Administration in Developing Areas: A role for Canadian Scholars. pp. 19-37

Keywords: Canadian scholars; educational administration; professional preparation; nature of development; organizational functions; public administration

Shute, J. C. Education and Third World Rural Development. pp. 38-48

Keywords: food system; professionals and scholars; human resource development technology transfer

Fussl, K. and Kubina, C. Determinants of the Development of Education in PostWar Berlin. pp. 49-72 
Keywords: Berlin school system; restoration and innovation; educational development; unified school system

\section{Reviews-Recensions}

Mitchell, S._ The Canadian Imperial View of Educational Change: An essay on a problem in the sociology of knowledge posed in the Meaning of Educational Change. pp. 73-87

Ray, D. Empirical Research in Education by G. de Landsheere. pp. 88-89.

\section{Volume 13, number 2, 1984}

Singh, J. B. Education and Development: Operative and espoused views of the school's role in Guyana. pp. 9-21

Keywords: Guyana; operative views; society; adjust; development of the individual

Torres, C. A. The Political Economy of Adult Education in Latin America. pp. 2236

Keywords: Latin America; adult education; public policy formation; financial expenditure; politics

Urwick, J. Urban Versus Territorial Bias in the Provision of Education: The quality of provision in an African school network. pp. 37-61

Keywords: Africa; spatial inequality, education; developing countries; secondary school; education provision

Hossain, N. and crisler, L. Perceived Earnings of Bangladeshi Students: The effects of a foreign degree. pp. 62-72

Keywords: Bangladesh; foreign degrees; perceived economic and social gains; labor market.

Tambo, L. An Appraisal of School Reform Objectives in Cameroon. pp. 73-77

Keywords: school reform; Cameroon; community; curriculum; teacher

\section{Reviews-Recensions}

Ray, D. Encyclopedia of Educational Research. pp. 78-79.

Volume 14, number 1, 1985

Race, Culture, and ideology in Canadian Education

Laferrière, M. Languages, Ideologies, and Multicultural Education in Canada: Some Historical and sociological perspective. pp. 5-15 
Keywords: language of education in Canada; socio-cultural groups; Canadian provinces

Laferrière, M. Education interculturelle et multiculturalism: ambiguite et occultations. pp. 16-28

Mots-clés: Education interculturelle; multiculturelle; franchir les barrières.

Keywords: intercultural education; multicultural education; transcending barriers

Laferrière, M. L'education des enfants des groupes minoritaires au Quebec: de la definition des problemes par les groups eux-memes a l'intervention. pp. 2948

Mots-clés: Québec; enfants d'origine immigrée; perspectives sociologiques; la langue française.

Keywords: children of immigrant origin; Quebec; sociological perspective; French language.

Laferrière, M. Language and Cultural Programs for Ethnic Minorities in Quebec: a critical view. pp. 49-58

Laferrière, M. Blacks in Quebec: minorities among minorities. pp. 59-82

Mots-clés: Québec; minorité au milieu des minorités; inégalité sociale.

Keywords: Quebec; minority within minorities; social inequities.

Laferrière, M. Lecture et situation minoritaire. pp. 83-92

Mots-clés: Statut des enfants des goupes minoritaires; dispositions pour la lecture; motivation.

Keywords: child minority group status; reading aptitude; motivation

Laferrière, M. L'école et l'intégration des communautés ethno-culturelles au Québec: une étude des perceptions des leaders ethniques. pp. 93-107

Mots-clés: Montréal; expectations des dirigeants ethniques; qualité et organisation des écoles publiques.

Keywords: Montreal; expectation of ethnic leaders; quality and organization of public schools

\section{Reviews-Recensions}

Zachariah, M. The Influence of the Carnegie, Ford, and Rockefeller Foundations on American foreign policy. Edward H. Berman. pp. 108-110

Cho, S. W. Applied Psycholinguistics: An introduction... pp. 110-116

Friesen, J. Cultural Diversity and Canadian Education: Issues and innovations. pp. 116-117

Sharp. L. W. World Hunger: The responsibility of Christian Education. pp. 117121. 
Al-Rubaiy, A. Two Decades of Internationalism in American Education. pp. 6-11 Keywords: Health of education; globalization in education;

Baksh, I. Students' Background, Educational Perceptions and occupational Expectations in Trinidad. pp. 12-27

Keywords: secondary school, Trinidad; casual model; students' attitudes; academic ability; socioeconomic status

Burgess, D. A. University of the West Indies: Current developments and future Prospects. pp. 28-38

Keywords: Caribbean region; regional institution; administrative organization; financing; restructuring

Rogers, T. W., and Wenxiu, L. Comparative Analysis of Attitudes towards Mathematics of Senior High School Students in British Columbia. pp. 39-58

Keywords: grade 12; British Columbia: mathematics; home support; personal perception of mathematics; mathematics curriculum

Wenxiu, L. Developments and Interrelationships of Higher Education in New China. pp. 59-71

Keywords: statistical overview; development of higher education; china; economy politics; legal system; secondary education

\section{Reviews-Recensions}

Goldsmith, Claire. Participation: Cultural Analysis for Policy Studies. pp. 72-75

Kanyike, L. K. The World Crisis in Education: The view from the Eighties by Philip h. Coombs. pp. 76-78

Friesen, J. Education and Canadian Multiculturalism: Some problems and some solutions by Daniel Dorotich. pp. 79-80

\section{Volume 15, number 1, 1986}

Hayhoe, R. Intellectual Freedom and the Chinese University. pp. 5-24

Keywords: reforms; china; political-legal development; intellectual freedom; Chinese socialism

Ghosh, R. Women's Education in the Land of the Goddess Saraswati. pp. 25-44

Keywords: education of women; barriers; religious structures; equality of opportunity

Lam, J. Characteristics and Constrains of Public School Environments: A comparison between Canadian and English schools. pp. 45-63

Keywords: public schools; school environment; constrains; organization; funding 
Samaroo, N. Schooling in a Plural Society: An alternative framework. pp. 64-81 Keywords: plural society; role of school; society; capitalism; colonial expansion

\section{Reviews-Recensions}

Chamberlain, R. In the Beginning: a Scientist Shows why the Creationists are wrong. pp. 82-84

Renihan, P. an Introduction to Educational Administration in Canada. pp. 84-85

\section{Volume 15, number 2, 1986}

Shwartz, A. Teaching Hatred: The politics and morality of Canada's Keegstra affair. pp. 5-28

Keywords: Keegstra; hatred; provincial teachers' association

Hermon, E. Approches conceptuelles de léducation en vue de la comprehension internationale dans léntre-deux-guerres. pp. 29-52

Mots-clés: Approches conceptuelles; réformes de l'enseignement; relations internationales; éducateurs

Keywords: conceptual approaches; educational reform; international relations; educators

Ray, D. Assessing a Rolling policy Reform: rights for women and children in modern china. pp. 53-87

Keywords: rolling reforms; Chinese society; comparative analysis; rights of women

\section{Reviews-Recensions}

From the Book Review Editor's Desk. p. 88

Review Essay

Fiordo, R. Cultural Diversity and Canadian Education: Issues and innovations. pp. 92-97

\section{Book Review}

Michayluk, J. Children and Microcomputers: Research on the Newest Medium. pp. 97-99

Lacey, P. R. Immigrant Australians and Education. pp. 99-101 
Chinese Educators on Chinese Education

THEORETICAL OREINETTAIONS AND THE CONTEXT OF EDUCATIONAL REFORM

Zhiguang, Z. The Development and Present Situation of Educational Psychology in China. pp. 15-22

Zongli, H. The Development of the Economics of Education in China. pp. 23-32

Keywords: economic thought; Chinese education; nationalist government

Xing, Z. Research into Higher Education in China: Its emergence and prospects. pp. 33-39

Keywords: higher education; china; theoretical orientations

Ruiling, Z. Recherche en Education Comparee au cours de la re'reforme de lÉducation Chinoise. pp. 40-47

Mots-clés: Chine; éducation comparée; développement de l'éducation ; développements économiques.

Keywords: China; comparative education; education development; economic development.

Ting, Y. R. Foreign Language Teaching in China: Problems and perspectives. pp. 48-61

Keywords: foreign language teaching; china; Confucian social and education tradition; Dewey's progressivism;

Shiqi, H. China's Educational Relations with Foreign Countries. pp. 62-78

Keywords: Chinese policy on education; cooperative research; international organization

\section{EDUCATINAL REFORM POLICY AND ITS IMPACT ON VARIOUS TYPES AND LEVELS OF SCHOOLING}

Mingyuan, G. China's Education Heads for the Year 2000: On educational reform in China. pp. 79-85

Keywords: Chinese education; socialist economic modernization program; reform

Jingfang, Q. and Kexiao, H. On the Contemporary Reform of Secondary Education in the Eighties. pp. 86-102

Keywords: secondary education; china; reform; historical background; instructional reform; structural reform

Junfeng, Y. The Structure of Specialized Personnel and the Reform of VocationalTechnical Education. pp.103-113

Keywords: theory of vocational-technical education; economy; education; china; specialist education 
Qinglian, Y. The Strategic Position and Prospects of Teachers' Education. pp. 114-122

Keywords: Chinese teacher education; policy; reform

Benyi, G. Adult Education in the Course of Reform. pp. 123-132

Keywords: adult education; historical background; unified leadership; national adult education

Congfang, W. Pre-Service and In-Service Teacher Education in China. pp. 133145

Keywords: teacher education; china; philosophy and research; reform

Wing-chung, C. Primary Teacher Education in China: The case of Harbin. pp. 146-161

Keywords: primary teacher education; socio-cultural characteristics; Harbin; modernization

Wenxiu, L. the Significance of Recent Reforms for Higher Education. pp. 162171

Keywords: reform; education system; china; higher education administration; political-ideological education

Shujun, D. Vocational Universities in China. pp. 172-182

Keywords: vocational universities; china; higher institution; economic needs; higher education

\section{REVIEWS AND ESSAYS}

Price, R. F. Contemporary Approaches to Moral-Political Education. pp. 183-189

Rosen, S. Survey Research in the People's Republic of China: Some methodological problems. pp. 190-197

Henze, J. Statistical Documentation in Chinese Education: Where reality ends and myth begins. pp. 198-210

Cumming, A. Evaluations and Developments of Foreign Language Teaching in China. pp. 211-220

McLean, L. Lessons from the Evaluation of Canada-China Human Resources Development Projects. pp. 221-228.

\section{Volume 16, number 2, 1987}

Dickinson, G. Toward Equal Status for Catholic Schools in Ontario: The supreme court of Canada examines constitutional issues. pp. 5-23

Keywords: roman Catholic schools; Ontario; government grants; constitutional history; politics; litigation;

Wilson, D. Two Decades of Planned Educational Expansions in Developing Nations: An Examination of successes, failures, and change. pp. 24-38 
Keywords: success; failure; changes; educational planning; developmental theories; primary education; post-secondary education

Bacchus, M. K. The Political Context of Education in the Developing Countries. pp. 39-54

Keywords: curriculum; vocationalisation; developing countries; British colonial context; productivity; development strategies

Iram, Y. Changing Patterns of Immigrant Absorption in Israel: Educational Implications. pp. 55-72

Keywords: Israel; Jewish population; reform; economic absorption

Altbach, P. Knowledge Networks in the Modern World. pp. 73-88

Keywords: dissemination of knowledge; informal communication; western industrial nations

\section{Reviews-Recensions}

Ray, D. Changing Patterns of Secondary Education: An international comparison. pp. 89-92

Ryan, A. Collecting Evaluation Data: Problems and solutions. pp. 92-94

Wheeler, R. The Logic of Surprise in International Conflict. pp. 94-97

\section{Volume 17, number 1,1988}

Magsino, R. Educational Linguistic-Cultural Rights in Three Countries: Toward Policy Evaluation. pp. 2-26

Keywords: comparative study; evaluation alternative; cultural diversity; sociological perspective; policy developments; United Sates; the Philippines; Canada

LaMonte, R. B. The Education of Palestine Refugees on the West Bank and Gaza Strip: The role of the United Nations relief and works agency. pp. 27-35

Keywords: elementary, preparatory, vocational and teacher education; Palestinians; UN relief works; refugees

Osunde, E. Diversifying the Secondary School Curriculum in Nigeria: Problems and policy options. pp. 36-44

Keywords: Nigeria; diversifies curriculum; schooling

Tilak, J. B. Economics of Vocationalization: A review of evidence. pp. 45-62

Keywords: Vocationalization; secondary education; India; economic efficiency

\section{Reviews--Recensions}

Longtin, L. Accès et Succès à I'Université. pp. 63-64 
Evans, B. China's Education and Industrialized World: Studies in cultural transfer. pp. 65-67

Torres, C. The National Unified School in Allende's Chile: The role of education in the destruction of a revolution. pp. 67-70

Spronk, B. Patriarchy, Party, Population, and Pedagogy: Essays on education and development. pp. 70-74

Minnis, j. Adult Participation in Swedish Higher Education: A study of Organizational Structure, educational design and current policies. pp. 74-77

Paul. R. Founders: Innovators in education, 1830-1980. pp. 77-80

\section{Volume 17, number 2, 1988}

\section{IN DEBATE}

Woodhouse, H. and Bloom, L. Nigerian Higher Education: Policy and Practice. pp. 5-21

Keywords: Nigerian University system; national policy; education; objectivity and tolerance; self-sacrifice

Hatt, D. G. Response to "Nigerian Higher Education"-A Critique of the Liberal Position. pp. 22-27

Woodhouse, H. Cultural Advertisement as Cultural Critique- A rejoinder to Hatt. pp. $28-30$

Kanyike, L. K. Success and Failure as Issues in School Provision: The Kenyan case. pp. 31-47

Keywords: evaluation criteria; African socialism; educational policy; Kenya; structure of acquisition

Weitz, S. Reforming Arts Education and the School System in Israel. pp. 48-60

Keywords: receptiveness; Israel; attitude; leisure time; validity; traditional norms

Burgess, D. and Bayley, S. Britain's Education Reform Act: A new Direction for Education. pp. 61-74

Keywords: educational reform; educational legislation; Britain; Canadian education; policy makers; ideological bases; national curriculum; religious worship; higher education; restructuring

\section{Notes and Comments}

Enaohwo, J. O. Age-Earnings Profiles of Educated Persons in the Nigerian Setting. pp. 75-82

Newark, J. Cost Analysis in Education: A tool for policy and Planning. pp. 83-87 


\section{Reviews--Recensions}

Clarkson, P. Teaching Children of the Poor: An Ethnographic study in Latin America. pp. 88-90

Morrison, T. Higher Education in the Third World. pp. 91-92

Murgatroyd, S. Management and Psychology of Schooling. pp. 93-94.

\section{Volume 18, number 1, 1989}

Zachariah, M. People's Movements and Reform of Formal Education: Reflections on Kerala Sastra Sahitya Parishad (KKSP) in India. pp. 3-19

Keywords: education; role of the sate in development; progressive reform; basic education

Cheng, W. Teacher Prestige in China. pp. 20-35

Keywords: attitudes; school teachers; occupational prestige; china; national development; political leadership; economic development

Coleman, M. Western Education, American Indian and African Children: A comparative study of pupil motivation through published reminiscences, 1860s-1960s. pp. 36-53

Keywords: motivation, Africa; missionary and government schools; personal factors; cultural background; institution; curriculum

Krugly-Smolska, E. Theoretical Models in Comparative Education: An attempt at Synthesis. pp. 54-64

Keywords: comparative education; overarching theories; points of infinitum; Holmes

\section{Reviews--Recensions}

Notes from the Book review Editor. pp. 65-66

Mvesso, A. École et Culture Technique; experiences européennes. pp. 67-69

Masserschmidt, D. The Background Jungle: Formal Education in disadvantaged rural areas-a sri Lankan case. pp. 70-71

Mazurek, K. Revolution Through reform: A comparison of Sarvodaya and Conscientization. Pp. 72-76

Counihan, M. Servicing Careers n the Post-Employment society. pp. 77-78.

\section{Volume 18, number 2, 1989}

Bacchus, M. K. Educational Needs of Small Nation States with Special Reference to Education at the post-Secondary level. pp. 5-17 
Keywords: structural features; education; economic and cultural vulnerability. Post-secondary education

Saint-Germain, M. Analyse de Quelques Facteurs Relatifs au Volet Linguistique de la Réforme. pp. 18-33

Mots-clés: Langues maternelles; réforme de l'enseignement; situation de diglossie; prestige; politique linguistique; contrôle de qualité.

Keywords: Mother tongues; educational reform; diglossic situation; prestige; linguistic policy; quality control.

DeBeauvais, M. Les changements sans réforme: une Nouvelle tendance internationale dans le Domaine de I'Education? pp. 34-41

Mots-clés: Politique d'enseignement; réformes globales; qualité de l'enseignement; tronc commun; recherches sur l'éducation; éducation comparée.

Keywords: educational policy; global reforms; quality of education; core curriculum; educational research; comparative education

Ben-Peretz, M. and Menis, J. Biology Achievement at Three School Levels across English Canada: Results from the second international science study. pp. 4252

Keywords: teaching biology; Canada; school levels; misconceptions

\section{Notes and Comments}

Bagley, C. Self-Concept and Achievement in British and Anglo Canadian High School Students. 77-78

\section{Book Reviews}

Owen, M. Notes from the Book Review Editor. pp. 79-83

Wilson, V. Educating Reason: Rationality, critical thinking, and education. pp. 8486

Girad, A. Le programme Andin: cobtribution de I'OIT a un Project-Pilote de Cooperation Technique Multilaterale. Pp. 87-88

Osborne, K. Political Education in Britain. pp. 89-91

\section{Volume 19, number 1, 1990}

Ray, D. Languages and Political Purpose: The Canadian case. pp. 4-15

Keywords: teaching languages; aboriginal; English and French communities

Gauthier, N. F. Luttes Ideologiques et Cultures Institutionnelles en education Minoritaire: Le Cas de I'Ontario Français. pp. 16-31

Mots-clés: Canada; autonomie; minorité francophone; écoles secondaires; écoles publiques. 
Keywords: Canada; autonomy; Francophone minority; secondary schools; public schools

Wilson. D. N. The Deleterious Impact of Rate-of-Return Studies on LDC Education Policies: An Indonesian Case. pp. 32-49

Keywords: rate-of-return studies; Indonesia; secondary education; public and private institutions; qualitative improvements

Violato, C. and Odhiambo, K. T. The Social Ecology of Literacy and Achievement in Primary Schools of Kenya. pp. 50-60

Keywords: social ecology; academic achievement; primary school; Kenya; literacy; mathematics

Abagi, J. and Cleghorn, A. Teacher Attitudes towards the Use of English, Kiswahili, and Mother Tongue in Kenyan Primary Classrooms. Pp. 61-71

Keywords: Kenya; teachers' attitudes; English; Kiswahili; primary school; mother tongue; educational policy; teacher training

\section{Reviews--Recensions}

Owen, M. Notes from the Book Review Editor. pp. 72-75

Coulter, R. P. Paving Pathways to Work. pp. 75-79

Cochrane, D. The Curriculum: Problems, politics, and possibilities. pp. 79-82

Pannu, R. Education and the Process of Change. pp. 82-84

Longtin, L. Elements pour un Bilan de la Premiere Annee du. pp. 84-85

Spronk, B. Technology, Gender, and Power in Africa. pp. 85-88

Bacchus, M. K. Multiple-Shift Schooling: Design and Operation for Cost effectiveness. pp. 88-89.

\section{Volume 19, number 2, 1990}

Parker-Jenkins, M. No More Stick: An examination of the legal background to Britain's abolition of corporal punishment. pp. 5-17

Keywords: abolition of corporal punishment; British State schools; reformist legislation; European Court of Justice

Tambo, L. Strategic Concerns in Curriculum Development for Cameroon Schools. pp. 18-39

Keywords: Cameroon; educational reform; curriculum change; teacher education

Paille, P. Quelques elements pour une Clarification du camp de I'education a Vocation Internationale. pp. 40-60

Mots-clés: Education pour la paix; éducation universelle; éducation pour une compréhension mondiale; éducation internationale. 
Keywords: peace education; global education; education of the world understanding; international education

Wilson, D. A Comparative Study of Open Universities in Thailand and Indonesia. pp. 61-88

Keywords: Thailand; open universities; Indonesia; administration; structure; social demand

\section{Reviews--Recensions}

Ricker, E. The Vexed Question: Denominational Education in a Secular age. pp. 89-94

Appavoo, P. India's Information Revolution. pp. 94-96

Archer, W. Comparative Adult Education: State of the Art with annotated Resource guide. pp. 96-98

Bates, T. Educational Technology: Its creation, development, and cross cultural transfer. pp. 98-100

Cornell, M. L. Benefiting from Basic Education, School quality and Functional literacy in Kenya. pp. 100-103

Jain, S. Japanese Schooling: Patterns of Socialization, Equality, and Political Control. pp. 103-107

Wilson, D. N. Vocationalizting Education: An international perspective. pp. 107110

\section{Volume 20, Number 1, 1991}

\section{The development context}

Ariyaratne, A. T. Does development education in the more developed world make a difference in the less developed world? p.4-12

Keywords: development education; Sarvodaya Shramadana; Canada

Moffat, J. Networks within Canada; partnerships abroad:The new challenges for development education. p.13-20

Keywords: development education; networks; partnerships; social change

\section{International trade and debt}

Romana, A. Third world debt vis-a-visa the informal economy---- emerging new responses to the modern crisis. p.22-73

Keywords: informal economy; antonomous activity; dependent world debt

Tomlinson, B. CIDA's sharing our future: Analysis and implications for Canadian NGOs. p. 74-85

Keywords: CIDA; Canadian NGOs; private sector; sustainable ecological development; gender; human rights 


\section{Sustainable development}

Arnold, J., \& Harvey, J. Reflections on sustainable development. p. 87-96

Keywords: sustainable development; participatory development; community residents

\section{Schools and Postsecondary institutions}

Cronkhite, L. Development education in schools and postsecondary institutions. p. 98-113

Keywords: development education; Canadian educational institutions; obstacles

James, S. Development education in the university: Research and praxis. p. 114123

Keywords: development education; university level

\section{Social movements}

Howlett, D. Social movements and development education. p. 125-130

Keywords: development education; social movements; ProCanada Network

Linds, W. Walking together: Development education and Canada's social movements. p. 131-142

Keywords: development education; popular education; Eastern Caribbean; Saskatchewan

\section{Postscript on process}

Gingras, P. Developing the process for an interactive workshop. p. 143-148

Keywords: workshop; adult learning

\section{Bibliography}

Dobrowolsky, A., \& Depass, C. Development Education: A selective bibliography. p. 149-167

Keywords: development education; bibliography; debt; children; church; sustainable development; food; human rights; Canadian NGOs; Global NGOs; peace; women; technology transfer; curricular guides; audiovisual materials; resources; conference proceedings

\section{Volume 20. Number 2, 1991}

Cornell, M. Looking forward by looking back: A retrospect on women, education, and development in Kuwait. p.7-23

Keywords: women education and employment; Kuwait 
Lam, Y. Nature and patterns of school environment: Comparison of six sociocultural settings. p.24-41

Keywords: comparison; school environment; social condition; Manitoba, Canada; Cheshire, England; Taiwan; Hong kong; Shanghai, China; Swaziland

Poonwassie, D. Political influence and curriculum change: The case of Guyana. p.42-53

Keywords: political ideology; curriculum reform; Guyana

London, N. The concept of the high school in an emerging society: An analysis of major trends. p.54-70

Keywords: concept of the high school; emerging society; Trinidad; Tobago

\section{Review essay}

Jansen, J. Education and socialism in the Third World: In search of explanations. p.71-75

Carnoy, M., \& Samoff, J. Education and socialism in the Third World: A response. p. $75-80$

\section{Reviews}

Ross, K.N., \& Mählck, L. (Ed.).(1990). Planning the quality of education: The collection and use of data for informed decision making. Paris: UNESCO: International Institute for Educational Planning. Reviewed by Crespo, M. p.81-86

Epskamp, K. P. (1989). Theatre in search of social change: The relative significance of different theatrical approaches. The Hague: Centre for the Study of Education in Developing Countries. Reviewed by Nothof, A. p.8791

Gumbert, E.B. (1989). Fit to teach: Teacher education in international perspective. Atlanta: Center for Cross-Cultural Education, Georgia State University. Reviewed by Shuker, R. p.91-94

Lauder, H., \& Brown, P. (Ed.). (1988). Education in search of a future. London: The Falmer Press. Reviewed by Stephan, W. p.94-96

Himmelfarb, H.S., \& DellaPergola, S. (Ed.). (1989). Jewish education worldwide: Cross cultural perspectives. New York: University Press of America.

Reviewed by Ray, D. p.96-99

Thomas, R.M.(Ed.). (1990). International comparative education: Practices, issues and prospects. London: Pergamon. Reviewed by Alladin, I. p.99-101 
Crespo, M. Tendances récentes dans l'enseignement supérieur: Un aperçu comparative/ Recent Trends in Higher Education: A comparative perspective. p.3-7

Keywords: prologue; higher education

Barot, E., \& Hénault, G. La problématique de l'enseignement supérieur dans les pays en développement: Les défis d'une mission en mouvance liés à une nécessaire gestion stratégique des universités. p.8-19

Mots-clés: Universités du Tiers-monde; autonomie directoriale; marché des emplois; insuffisance des fonds; coopération internationale.

Keywords: third world universities; managerial autonomy; job market; underfunding; international cooperation

Vught, F. Governments and higher education in Western Europe. p.20-31

Keywords: Western European governments; higher education systems; institutional management

Wasser, H. Recent trends in American higher education. p.32-44

Keywords: American higher education; changes and trends; evaluation and accountability; societal needs

Cazalis, P. L'enseignement supérieur au Canada au seuil des années 90: état de la situation et perspectives. p. $45-68$

Mots-clés: Canada; système d'enseignement supérieur; distribution; géographique; financement; enrôlement et traditions.

Keywords: Canada; higher education system; geographic distribution; financing; enrolments and traditions.

McMahon, W. Rates-of-return in LDC educational policy: A reply to David N. Wilson's critique. p.69-75

Wilson, D. Rates-of-return in LDC educational policy formulation: Rejoinder to Walter W. McMahon's assertions. p.76-83

\section{Book reviews}

Grieg, S., Pike, G.., \& Selby, D. (1989). Greenprients: For changing schools. London: Kogan Page. Reviewed by Mather, S. p.84-85

Selman, G., \& Dampier, P. (1991). The foundations of adult education in Canada. Toronto: Thompson Educaitonal Publishing. Reviewed by Spencer, B. p.8587

Holmberg, B. (1989). Theory and practice of distance education. London: Routledge. Reviewed by Paul, R. p.87-89

Bray, M., \& Lillis, K. (1988). Community financing of education. Oxford: Pergamon Press. Reviewed by Bezeau, L. p.89-91 
Walford, G. (Ed.). (1989). Private schools in ten countries: Policy and practice. London: Routledge. Reviewed by Richardson, T. p.91-93

\section{Volume 21, Number 1, 1992}

Gillett, M. Goals of Canadian women's organizations: The first wave. p.5-19 Keywords: Canadian women's movement; identity; God and good works; temperance and the home; social reform; Anti-war; the vote

Turner, J. Complementarity, ethnomathmatics, and primary education in Bhutan. p.20-43

Keywords: complementary modes of knowing; mathematic education; games and play activities; Bhutan

Brown, J. Educational innovation in developing countries: Some considerations for the international consultant. p.44-54

Keywords: educational innovation projects; developing countries

Binda, K.P., \& Mzumara, P.S. Job performance of inservice trained and untrained elementary school principals in Malawi. p.55-68

Keywords: primary school administration; Malawi; performance of principals

\section{Book reviews}

Tennant, M. (Ed.). (1991). Adult and continuing education in Australia: Issues and practices. New York: Routledge, Chapman \& Hall. Reviewed by Spencer, B. p.69-73

Muller, J. (Ed.). Education for work, education as work: Canada's changing community colleges. Toronto: Garamond Press. Reviewed by Sheck, C. p. $73-76$

Kumar, K. (1989). Social character of learning. New Delhi: Sage. Reviewed by Zachariah, M. p.76-79

Walford, G. (1990). Privatization and privilege in education. London: Routledge. Reviewed by Sweet, R. p.79-82

Poster, C., \& Kruger, A. (Ed.). (1990). Community education in the Western World. New York: Routledge, Chapman \& Hall. Reviewed by Peruniak, G. p.82-85

Archer, D., \& Costello, P. (1990). Literacy and power: The Latin American Battleground. London: Earthscan Publications. Reviewed by Smith, S. p.8589

Merriam, S.B., \& Caffarella, R.S. (1991). Learning in adulthood: A comprehensive guide. San Francisco: Jossey-Bass. Reviewed by Thompson, G. p.90-91 
Bray, M. (Ed.). Ministries of education in small states: Case studies of organization and management. London: Commonwealth Secretariat.

Bray, M. (Ed.). Making small practical: The organization and management of ministries of education in small states. London: Commonwealth Secretariat. Jointly Reviewed by Bacchus, M. p.91-95.

\section{Volume 21, Number 2, 1992}

Bray, M., \& Chhoeda, T. The implications of size for educational development in small states: The case of Bhutan. p. 5-22

Keywords: educational development; Bhutan; implication of smallness

Bracegirdel, P. The social relations of education in UNO's Nicaragua (19901991). p. 23-39

Keywords: economy; changes; educational system; Nicaragua

Stromoquist, N. Conceptual and empirical advances in adult literacy. p. 40-54

Keywords: adult literacy; theory; practice

Spencer, B. Labor education in the UK and Canada: What do workers do and what should they be offered on Union courses. p. 55-68

Keywords: labor education; limitations; alternatives; union courses; UK; Canada

\section{Book reviews}

Cassara, B.B. (Ed.). (1990). Adult education in a multicultural society. New York: Routledge, Chapman \& Hall. Reviewed by Collins, M. p. 69-72

Fuller, B. (1990). Growing up modern: The western state builds third-world schools. New York: Routledge, Chapman \& Hall. Reviewed by Taylor, G. p. $72-77$

Wall, D., \& Owen, M. (Ed.). (1992). Distance education and sustainable community development. Edmonton, AB: Canadian Circumpolar Institute with Athabasca University Press. Reviewed by Black, D. p. 77-80

Thomas, A.M. (1991). Beyond education: A new perspective on society's management of learning. San Francisco: Josey-Bass. Reviewed by Spencer, B. p. $80-82$

\section{Review essay}

Kwapong, A.A., \& Lesser, B. (Ed.). (1990). Capacity building and human resource development in Africa. Halifax: The Lester Pearson Institute for Internaitonal Development.

Hallak, J. (1990). Investing in the future: Setting priorities in the developing world. Oxford: Pergamon Press. 
Jointly Reviewed by Wilson, D. p. 82-93

\section{Volume 22, Number 1, 1993}

Lin, J. Ethnic relationships and minority education in Guangxi, China: A case study. p. 5-21

Keywords: inequality; educational opportunity; minority children; ethnic relationship; Guangxi

Mundy, K. The case for universal primary education revisited: The Tanzanian and Zimbabwean experience in comparative and international perspective. p. 2242

Keywords: primary education; Tanzania; Zimbabwe

Dei, G.J.S. Learning in the time of Structural Adjustment Policies: The Ghanaian experience. p. 43-65

Keywords: educational reforms; Ghana; SAPs; elementary schools

Wright, H. What is Shakespeare doing in my hut? "A" level literature and the Sierra Leonean student. p. 66-86

Keywords: literature education; Sierra Leone; “A” level program

\section{Book reviews}

Hayhoe, R. (Ed.). (1992). Education and modernization: The Chinese experience. Toronto: Pergamon Press/ OISE Press. Reviewed by Evans, B. p. $87-88$

Carlson, D. (1992). Teachers and crisis: Urban school reform and teachers' work culture. New York: Routledge, Chapman \& Hall. Reviewed by Kompf, M.

p. $89-90$

Liston, D., \& Zeichner, K. (1991). Teacher education and the social conditions of schooling. New York: Routledge, Chapman \& Hall. Reviewed by Wright, I. p. 91-92

\section{Review essay}

Evans, K., \& Haffenden, I. (Ed.). (1991). Education for young adults: International perspective. New York: Routledge, Chapman \& Hall.

Corner, T.E. (Ed.). (1991). Learning opportunities for adults. New York: Routledge, Chapman \& Hall. Jointly Reviewed by Wickett, R. p. 93-97 
Reimer, J. et al. Canadian nonformal development educaton: A typology of educational strategies. p. 1-16

Keywords: development education(deved); Canada; adult education; deved practice

Rousseau, R. et al. Perceptions du professeur d'université en education: etude interculturelle. p. 17-50

Mots-clés: Espagne; Portugal; Québec, Canada; évaluation des enseignants; niveau universitaire.

Keywords: teacher evaluation; Spain; Portugal; Québec, Canada; university level.

Campbell, C. The German Dual System of Apprenticeship Training for youth: A best-practices study. p. 51-67

Keywords: youth education; apprenticeship training; German

Maclure, R. School reform in Burkina Faso: The limited prospects of decentralization and local participation. p. 69-87

Keywords: Burkina-Faso; educational reform; political economy; decentralization.

\section{Book reviews}

Houle, C. (1992). The literature of adult education: A bibliography essay. San Francisco, CA: Jossey-Bass. Reviewed by Epstein, R. p. 89-91

Magolda, M. (1992). Knowing and reasoning in college: Gender related patterns in students' intellectual development. San Francisco, CA: Jossey-Bass. Reviewed by Brindley, J. p. 91-93

Bailey, P. (1990). Reform the people: Changing attitudes towards popular education in early twentieth century China. Vancouver, BC: UBC Press. Reviewed by Rvans, B. p. 93-94.

\section{Volume 23, Number 1, 1994}

\section{Editorial}

Poonwassie, D. Reflection. P.1-2

Miller, R. The world crisis in education: Another view. p. 3-12

Wilson, D. On teaching the methodology of comparative education: Why are there so few courses in Canada? p. 13-24

Berry, J. Sharing whose future? - Canadian universities and international cooperation. p. 25-40 


\section{Articles}

Birzéa C. La planification de l' education en situation de crise: le cas des pays en transition. p. 41-50

Mots-clés: démocratie; éducation; pays en transition.

Keywords: democracy; education; transiting countries.

Gaziel, H. Mise en œure de la politique educative: Base théoriques et application pratique. p. 51-66

Mots-clés: politique de l'enseignement; actions concrètes; cadre de travail intégratif et conceptuel/.

Keywords: educational policy; concrete actions; integrative conceptual framework.

Shen, J., \& Chan, G. Mao Zedong's educational thought revisitEd. p. 67-82

Keywords: Mao Zedong; educational thought; non-formal education; Chinese education

\section{Book reviews}

Hawkins, F. (1991). Critical years in immigration. Canada and Australia comparEd. Montréal: McGill-Queens University Press.

Roberts, B. (1988). Where they came: Deportation from Canada, 1900-1935. Ottawa: University of Ottawa Press.

Matas, D., \& Simon, I. (1989). Closing the doors: The failure of refugee protection. Toronto: Summerhill. Jointly Reviewed by Ray, D. p. 83-86

McIlroy, J., \& Westwoods, S. (Ed.). (1993). Border country: Raymond Williams in adult education. Leicester: National Institute of Adult Continuing Education (England and Wales). Reviewed by Spencer, B, p. 86-88

\section{Volume 23, Number 2, 1994}

Shen, J. Nation-state approach and world systems analysis; A new perspective on comparative education. p. 1-12

Keywords: world system analysis; nation-state approach; comparative education

Hughes, A. Understanding citizenship: A Delphi study. p. 13-26

Keywords: citizenship development; Delphi; Canada

Wilson, D. What education and training for which future? --- A comparative perspective. p. 27-60

Keywords: education; training; job market; Canada; comparison

Smith, K. A comparison of Scottish Gaelic education. p. 61-72

Keywords: Scottish Gaelic education; Ontario; Nova Scotia; Scotland; comparison 
Gamage, D. Is community participation in school management becoming an international phenomenon? p. 73-84

Keywords: community participation; school management; efficiency; parental involvement

Lin, J. The development and prospect of private schools in China: A preliminary study. p. 85-98

Keywords: private schools: China; history of private education

\section{Book reviews:}

Zachariah, M., \& Sooryamoorthy, R. (1994). Science in participatory development. The achievements and dilemmas of a development movement: The case of Kerala. London: Zed Books. Reviewed by Poonwassie, D. p. 99-101

Marcel, D., McLeod, K., \& Morris, S. (Ed.). (1993). Heritage languages and education. Oakville: Mosaic Press. Reviewed by Lee, J. p. 101-104

Emberley, P. C., \& Newell, W. (1994). Bankrupt education: The decline of liberal education in Canada. Toronto Buffalo London: University of Toronto Press. Reviewed by Findlay, L. M. p. 104-106

Wagner, D. (Ed.). (1987). The future of literacy in a changing world. Toronto: Pergamon Press. Reviewed by Owen, M. p. 106-110

\section{Volume 24, Number 1, 1995}

Dei, G. J. S. (Re)Conceptualizing Black Studies in Canadian schools. p. 1-19 Keywords: African-centred education; race; identity; representation; Canadian schools

Mouat, T., Choldin, E., \& Zachariah, M. Global education in Canadian schools: Formative influences, ideological perspectives, and emerging Christian Fundamentalist critiques. p. 21-45

Keywords: global education; value system; Canadian schools; Christian Fundamentalist ctiticisms

Mankoe, J. Potential impact of strategic planning in decentralizing a school system: The Ghana experience. p. 47-70

Keywords: educational reforms; Ghana; decentralization

Majhanovich, S., \& Majhanovich, L. Implications of intra-European mobility on education: Education for immigrants and refugees. p. 71-82

Keywords: migration in Europe; immigrants and refugees education; Canada

Asagwara, K. Political legitimacy and educational policy in Nigeria in the 1970's: The case of the Nigerian military government, 1966-1976. p. 83-98 
Keywords: political legitimacy; national education policy; Nigeria; welfare polictics

\section{Book reviews:}

Arnup, K. (1994). Education for motherhood: Advice for mothers in twentiethcentury Canada. Toronto: University of Toronto Press. Reviewd by Coulter, R. p. $99-100$

Bacchus, M. (1994). Education as and for legitimacy. Waterloo: Wilfred Laurier University Press. Reviewed by Tennyson, B. p.100-102

Rooyen, L., \& Louw, N. (1994). Sexuality education, a guide for educators. Pretoria: J. L. van Schaik, Academic. Reviewed by Sharpes, D. p. 102-103

\section{Volume 24, Number 2, 1995}

\section{Presidential address:}

Poonwassie, D. Tolerance. p. 1-13

Keywords: tolerance; UNESCO; Canada; education

\section{Articles:}

Kapoor, D. A case study from India: Empowering education, health and rural change. p. 14-35

Keywords: education; health; India; rural change; empowerment

Lewis, T. Including technology in the school curriculum of developing countries. p. $36-54$

Keywords: technology education; developing countries; implementation

Nowak-Fabrykowski, K., \& Sosnowski, A. Education in transition: Changes in the Polish school system. p. 55-64

Keywords: the Polish educational system; reforms; the role of teachers and parents

Tran, D. Education in Poland: A system in transition. p. 65-84

Keywords: Polish education reforms; national identity; transition

Shute, J. Assessing the medium-term impact of an institutional strengthening project. p. 85-94

Keywords: assessment; institutional strengthening project; national development

\section{Book reviews:}

Emberley, P., \& Newell, W. (1994). Bankrupt education: The decline of liberal education in Canada. Toronto, Canada: University of Toronto Press. Reviewed by Findlay, L. p. 95-97 
Kingsley, J., \& Callej, J. (Ed.). (1994). International education and the university. London and Paris: UNESCO. Reviewed by Ingalls, W. p. 97-99

The World Bank. (1994). Higher education: The lessons of experience. Washington, D.C.: The World Bank. Reviewed by Ingalls, W. p. 99-101

Battiste, M., \& Barman, J. (Ed.). (1995). First nations education in Canada: The circle unfolds. Vancouver: University of British Columbia Press. Reviewed by Smith, D. p.101-104

Marcel, D., McLeod, K., \& Morris, S. (Ed.). (1993). Heritage languages and education. Oakville: Mosaic Press. Reviewed by Lee, J. p. 105-108

Morris, S., McLeod, K., \& Marcel, D. (Ed.). (1993). Aboriginal languages and education: The Canadian experience. Oakville: Mosaic Press. Reviewed by Battiste, M. p. 108-111

Thom, D.J. (1993). Educational management and leadership: World, spirit, and deed for a just society. Calgary: Detselig. Reviewed by Smith, S. p. 111-117

Wagner, D. (Ed.). (1987). The future of literacy in a changing world. Toronto: Pergamon Press. Reviewed by Kachur, J. p. 118-122

Secada, W.G., Fennema, E., \& Adajian, L.B. (Ed.). (1995). New directions for equity in mathematics education. New York, NY: Cambridge University Press. Reviewed by Randhawa, B.S. p.122-125

\section{Volume 25, Number 1, 1996}

Eliadis, F. A comparative look at values and rights: What cultural differences can teach us. p. 1-28

Keywords: values; rights; cultural differences; dialogue; conflict; Canada

Ingalls, W. Improving the management of universities in developing countries. p. $29-42$

Keywords: improvement; effective institutions; administrative theory; the third world

London, N. Quality control in a colonial school setting: How it worked and for what purpose. p. 43-60

Keywords: quality control; colonial elementary schools; Trinidad; Tobago

Niu, X. Mao Zedong and Deng Xiaoping: A comparison of educational thought. p. $61-85$

Keywords: Mao's and Deng's educational thoughts; differences; political agenda; China

Li, X. Tuition reform in Chinese higher education. p. 86-99

Keywords: Chinese higher education; market economy; tuition system; reform 
Safr, V., \& Woodhouse, H. Eastern, Western, or Pan-European? Recent educational change in the Czech Republic. p. 100-121

Keywords: educational reform; the Czech Republic

\section{Reviews:}

Dubbeldam, L.F.B. et al. (1994). International yearbook of education. Volume XLIV-1994. Development, culture and education. Paris: UNESCO.

Hoppers, W., \& Komba, D. (Ed.). (1995). Productive work in education and training: A state-of-the-art in Eastern Africa. CESO Paperback No. 21. The Hague: Centre for the Study of Education in Developing countries.

Zinsser, J. (1994). A new partnership: Indigenous peoples and the United Nations system. Educational studies and documents 62. Pairs: UNESCO. Jointly Reviewed by Poonwassie, D. p. 122-126

Doutriaux, J., \& Margaret, B. (1995). The university-industry relationship in science and technology, Occasional Paper No. 11. Ottawa: Industry Canada. Reviewed by Owen, M. p. 126-128

Bastian, J., \& Bruno-Jofré (Ed.). (1994). Protestant educational conceptions, religious ideology and schooling practices: Selected papers. Monographs in Education XXII. Winnipeg: University of Manitoba. Reviewed by Owen, M. p. $128-130$

Wagner, D. A. (1993). Literacy, culture, and development: Becoming literate in Morocco. Cambridge: Cambridge University Press. Reviewed by Blunt, A. p. $131-134$

Hautecoeur, J. (Ed.). Alpha 94: Literacy and cultural development strategies in rural areas. Toronto: Culture Cocepts Inc. Reviewed by Blunt, A. p. 134137

Kerckhoff, A. (1993). Diverging pathways: Social structure and career deflections. Cambridge: Cambridge University Press. Reviewed by Kachur, J. p. 137-143

Wright, W., \& Associates. (1995). Teaching improvement practices: Successful strategies for higher education. Bolton, MA: Anker Publishing Compay, Inc. Reviewed by Moss, G. p.143-146

\section{Volume 25, Number 2, 1996}

\section{Editorial}

Sears, A., \& Print, M. Citizenship education: Canadian and international dimensions. p.v-vi 


\section{Articles}

Sears, A. 'Something different to everyone': Conceptions of citizenship and citizenship education. p. 1-16

Keywords: citizenship, citizenship education; Canada

Hughes, A., \& Sears, A. Macro and micro level aspects of a programme of citizenship education research. p. 17-30

Keywords: citizenship education; transition; democracy; development

Osborne, K. Education is the best national insurance: Citizenship education in Canadian schools. Past and present. p. 31-58

Keywords: citizenship education; Canadian schools; history; socialization; identity

Nicholas, A. Citizenship education and aboriginal people: The humanitarian art of cultural genocide. p. 59-107

Keywords: citizenship education; political culture; aboriginal people; colonialism; Canada

Joshee, R. The federal government and citizenship education for newcomers. $\mathrm{p}$. 108-127

Keywords: citizenship education; immigrants; language; economic participation; Canada

Strong-Boag, V. Claiming a place in the nation: Citizenship education and the challenge of feminists, natives, and workers in post-confederation Canada. $\mathrm{p}$. 128-145

Keywords: citizenship education; equality; feminists; natives; workers; postconfederation Canada

Case, R., \& Ross, M. On the need to dispel popular myths about law. p. 146-166

Keywords: law; politics; democracy; citizenship education; Canadian legal system

Cogan, J. Civic education in the United States: An historical and future perspective. p. 167-183

Keywords: civic education; educational reform; history; the United States

Print, M. From civics deficit to critical mass: The new civics education. p. 184198

Keywords: civics education; critical mass; Australia

Torney-Purta, J. The second IEA civic education project: Development of content guidelines and items for a cross-national test and survey. p. 199-214

Keywords: civic education; IEA project; cross-national test

Conley, M., \& Barot, E. Human rights education: Present and future trends. p. 215-233

Keywords: human rights; citizenship education; United Nations; Canada 
Ray, D. Russian-Canadian cooperation in curriculum development: Russian civic education, 1990-1996. p. 1-13

Keywords: civic education; Russian educational reform; cooperation; democratic; Canada

Guseva, L., \& Sosnowski, A. Russian education in transition: Trends at the primary level. p. 14-31

Keywords: Zankovian system; Russian educational reform; child development; primary school

Mays, A., Polyzoi, E., \& Gardner, S. The Czech experience of the initiation of educational change since 1989: Is a North American model applicable? p. 3253

Keywords: Fullan's model; social transformation; the Czech Republic; educational reform

Niu, X. Gender inequality in Chinese education. p. 54-75

Keywords: gender; discrimination; the Chinese educational system; culture

Hughes, A., \& Urasa, A. Transnational curriculum transfer and the role of feasibility assessment. p. 76-90

Keywords: transnational curriculum; feasibility; environmental education program; Canada; Tanzania

Asagwara, K. A perspective on free higher education in Nigeria. p. 91-117

Keywords: free higher education; financial burden; educational quality; Nigeria

\section{Volume 26, Number 2, 1997}

\section{Presidential address:}

Krugly-Smolska, E. Global and local challenges of/to the post-modern: Implications for education. p. 1-7

Keywords: globalization; post-modernity; post-industrialism; identity; education

\section{Articles}

Li, X., \& Walker, K. Autonomy and accountability in higher education: An analysis of Chinese higher education reform. p. 9-27

Keywords: autonomy; accountability; Chinese higher education; structural reform; market

Frenette, N., \& Quazi, S. L'effectif et la retention des élèves dans les écoles françaises en situation minoritaire au Canada. p. 28-41 
Mots-clés: Canada sauf Québec; taux de redoublement scolaire; minorités francophones.

Keywords: Canada outside Quebec; school retention rates; francophone minorities.

Dev, P., \& Belfiore, P. Mainstreaming students with disabilities: Teacher perspectives in India. p. 42-58

Keywords: special education; mainstreaming; teachers; India

\section{Forum}

Kelly, J. Giving birth to an elephant: Research on race in a white society. p. 59-70 Keywords: race; white society; identity; Canada

Msiska, F. The place of higher education in Malawi's development endeavours. p. 71-80

Keywords: higher education; economic growth; social development; Malawi

Tamukong, J. Strategies to mobilize local resources to finance secondary school education in the North-west province of Cameroon.

Keywords: secondary schools; education finance; Cameroon

MacLellan, D. Professional unionism: A new direction for teachers' union in Canada. p. 87-99

Keywords: teacher's unions; work culture; school organization; Canada

\section{Book reviews:}

Resnick, L., \& Wirt, J. (Ed.). Linking school and work: Roles for standards and assessment. San Francisco: Jossey-Bass Publishers.

Hautecoeur, J. (Ed.). Alpha 96: Basic education and work. Toronto and Hanburg: Cultural Concepts and UNESCO Institute for Education. Jointly Reviewed by Wotherspoon, T. p.100-103

James, C. (Ed.). (1996). Perspective on racism and the human services sector: A case for change. Toronto: University of Toronto. Reviewed by Ray, D. p. 103-105

Review of Roger Fieldhouse and Associates. A history of modern British adult education. Leicester, UK: National Institute of Adult Continuing Education. Reviewed by Spencer, B. p. 105-106

Alexander, A. (1997). The Antigonish movement: Moses Coady and adult education today. Toronto: Thompson Educational Publishing.

Lotz, J. \& Welton, M. (1997). Father Jimmy: Life and times of Jimmy Tompkins. Wreck Cove, Cape Breton: Breton Books. Jointly Reviewed by Spencer, B. p. $107-108$ 


\section{Volume 27, Number 1, 1998}

\section{Women and education}

Mansfield, S., \& Erskine, S. The Lass O'Pairts: Community education and women returners. p. 1-11

Keywords: community education; Scottish education system; feminist paradigm; women education

Clarke, V. Multicultural education issues in the Czech Republic: Existing context and some change initiatives for Rom citizens. p. 12-24

Keywords: social transformation; teacher training; education; Rom

Singh, J., Khanna, K., \& Bhasin, M. In India: Different curricula for girls and boys? p. 25-31

Keywords: enrolment rates; educational policy; parental resistance; girl education; Delhi

Reynolds, C. Squeeze plays and double binds: Women walking the leadership tightrope in education. p. 32-38

Keywords: leadership in education; women; technology

Yurchuk, J. Women's use of technology: An on-line international conference case study. p. 39-46

Keywords: gender equity; computer technology; internet and email

Fox, C., \& Lambert, R. Girls and education in Australia: An overview. p. 47-57

Keywords: equity education; Australia; disabled girls and women

Forum: Canadian Association for the Study of Women and Education International on-line email conference proceedings. p. 58-74

\section{Book reviews:}

Radcliffe, S., \& Westwood, S. (Ed.). (1993). Viva: Women and popular protest in Latin America. London: Routledge. Reviewed by Bennet-Clarke, C. \& Donaldson, E. p. 75-76

Odaga, A., \& Heneveld, W. (1995). Girls and schools in Sub-Saharan Africa: From analysis to action. Washington, D.C.: The International Bank for Reconstruction and Development. Reviewed by Hermary-Munro, M. \& Donaldson, E. p. 76-77

Grandea, N., \& Gibb, H. (Ed.). (1995). What's in a job? Equity in human resource development in Asia-Pacific economies. Ottawa, Canada: The North-South Institute. Reviewed by Bennet-Clarke, C. p.77-78

Jejeebhoy, S. (1995). Women's education, autonomy, and reproductive behaviour: Experience from developing counries. Oxford: Clarendon Press. Reviewed by Ellingson, C. p. 78-79 
Momsen, J., \& Kinnaird, V. (Ed.). (1993). Different places, different voices: Gender and development in Africa, Asia, and Latin America. London: Routledge. Reviewed by Innes, S. p. 79-80

Marchand, M., \& Parpart, J. (Ed.). (1995). Feminism postmodernism development. London: Routledge. Reviewed by Innes, S. p. 80-82

\section{Volume 27, Number 2, 1998}

Mc Andrew, M. La concentration ethnique dans les écoles de langue française de l'île de Montréal: Que pouvons-nous apprendre de la recherche américaine sur le "busing"? p. 1-24

Mots-clés: Québec, Montréal; intégration/ségrégation scolaire; politique du "busing" ou transport scolaire.

Keywords: Quevec, Montreal; school integration/segregation; "busing" policy.

Wilson, D. Reform of technological education curricula: A boundary-spanning approach. p. 25-41

Keywords: curriculum reform; technological education; Ontario; Canada

Ho, E., Chung, Y., \& Hung, F. Educational decentralization in South China: Increasing responsiveness and disparity between schools. p. 43-58

Keywords: educational reform; decentralization; local economic; disparity; social segregation; China

Pang, N. Organizational values and cultures of secondary schools in Hong Kong. p. $59-84$

Keywords: management culture; secondary schools; educational reform; Hong Kong

\section{Book reviews:}

Patten, B. (1998). The inside track. Toronto: Thompson Educational Publishing Company. Reviewed by Smith, M. p. 85-87

Wright, I., \& Sears, A. (Ed.). (1997). Trends and issues in Canadian social studies. Vancouver, Canada: Pacific Educational Press. Reviewed by Binda, K. p. 8991.

\section{Volume 28, Number 1, 1999}

Lee, M., \& Krugly-Smolska, E. Cultural understanding in prospective overseas teachers. p. 1-16

Keywords: pre-service teacher candidates; overseas teaching; culture 
Short, G. Teaching the Holocaust in Toronto --- A response to Lucy Dawidowicz. p. 17-36

Keywords: the Holocaust education; history course; high school; Toronto

Cheug, C., Yip, D., \& Mak, S. A comparison of teachers' perceptions on their competence and sources of knowledge across disciplines and levels of training. p. 37-59

Keywords: teaching practice; competence; training; experience; China

Shive, G. Information technology, school change and the teacher's role. p. 61-74

Keywords: web-based instruction; school change; teachers' role; Hong Kong

\section{Book reviews:}

Morgan, B. (1998). The ESL classroom: Teaching, critical practice, and community development. Toronto: University of Toronto Press. Reviewed by Hunter, J. p. 75-77

Case, R., \& Clark, P. (Ed.). The Canadian anthology of social studies: Issues and strategies for teachers. Burnaby, B.C.: Field Relations and Teacher InService Education. Reviewed by Hayes, D. p. 79-82

Sefa Dei, G. J., Mazzuca, J. McIsaac, E., \& Zine, J. (1997). Reconstructing "Drop-Out": A critical ethnography of the dynamics of black students' disengagement from school. Toronto: University of Toronto Press. Reviewed by Brown, Y. p. 83-86

Tompkins, J. (1998). Teaching in a cold and windy place: Change in an Inuit school. Toronto: University of Toronto Press. Reviewed by Binda, K. p.8789.

\section{Volume 28, Number 2, 1999}

Hutcheon, P. Multiculturalism: Good intentions and a clouded vision? p. 13-31 Keywords: multiculturalism; immigration; the Native rights; culture; Canada Magsino, R. The Canadian multiculturalism policy: A pluralist ideal re-visited. p. 33-51

Keywords: multiculturalism policy; unity; equality; conflicts; Canada

Stockden, E., \& Miranda, E. Multiculturalism and Liberal political theory: comments on Hutcheon's “clouded vision" and Magsino's "pluralist ideal revisited". p. 53-73

Keywords: multiculturalism; democracy; linguistic integration; Canada

Bellous, J. Just multiculturalism as a model for inclusion. p. 75-97

Keywords: multiculturalism; duality; inclusion; new identity; Canada

Bruno-Jofré, R. Manitoba schooling in the Canadian context and the building of a policy: 1919-1971. p. 99-128 
Keywords: identity formation; citizenship education; multiculturalism; Manitoba

Mitchell, S. Multiculturalism and the arts: Dual marginalities. p. 129-150

Keywords: multiculturalism; marginal group; racial difference

Jackson, R. Multiculturalism and religious education: Some observations from Britain. p. 151-180

Keywords: religious education; multicultural education; the UK Meijer, W. General education for an open pluralist society. p. 181-202

Keywords: liberal education; cultural diversity; pluralistic society

\section{Review essay}

Axelrod, P. (1997). The promise of schooling: Education in Canada, 1800-1914. Toronto: University of Toronto Press.

Strange, C., \& Loo, T. (1997). Making good: Law and moral regulation in Canada, 1867-1939. Toronto: University of Toronto Press.

Vance, J. (1997). Death so noble --- Memory, meaning, and the First World War. Vancouver: UBC Press.

Jointly Reviewed by Mitchell, T. “...Wrestling with the meaning of citizenship" p. 203-214

\section{Volume 29, Number 1, 2000}

Kwan-choi, T. Civic education in transition: The case of Hong Kong. p. 1-15

Keywords: civic education; official guidelines; actual practice; discrepancies; Hong Kong

Minnis, J. Education in the rentier state: Patterns and problems. p. 17-36

Keywords: educational policy; human capital; rentier states

Sefa Dei, G. J. Local knowledge and educational reforms in Ghana. p. 37-71

Keywords: educational reforms; social change; local knowledge; Ghana

Epp, W., \& Epp, J. Education and the European Union's evolving mythology. p. 73-86

Keywords: educational policy; identity; the European Union

Cheung, D., Ng, D., \& Hattie, J. The simplex structure of teachers' stages of concern about implementing a new curriculum. p. 87-103

Keywords: new curriculum; implementation; teachers' concern measurement

\section{Book reviews}

Sugunasiri, S. (1999). How to kick multiculturalism in its teeth. Toward a better tomorrow with critical compassion. Toronto: Village Publishing House. Reviewed by Majhanovich, S. p. 105-113 
Bray, M. (1999). The shadow education system: Private tutoring and its implications for planners. Paris: UNESCO: International Institute for Educational Planning. Reviewed by Pang, N. p. 115-117

\section{Volume 29, Number 1, 2000}

Yeung, S. Making connections in school history: How teenage students understand the history of Hong Kong and the handover. p. 1-19

Keywords: local identity; teenagers; history education; transition; Hong Kong

Kanu, Y. Curriculum, culture and teacher learning: A case study of an innovative teacher education program in Pakistan. p. 21-45

Keywords: culture; identity; teacher learning; discursive practices; Pakistan

Dhesi, A. Social capital and educational achievement: The case of India. p. 47-69

Keywords: social capital; academic achievement; parents education; community involvement; India

Wheeler, A. Reconceptualising teacher education: An experience from Pakistan. p. $71-90$

Keywords: in-service teacher education; educational change; reprofessionalism; Pakistan

Nelles, W. Mongolian-Canadian education, training and research cooperation: A brief history, 1973-2000. p. 91-106

Keywords: Mongolian-Canadian relations; educational cooperation; diplomacy cooperation

\section{Book reviews:}

Hawkins, J., \& Cummings, W. (Ed.). (2000). Transnational competence: Rethinking the U.S.-Japan educational relationship. Albany: State University of New York Press. Reviewed by Westfall, D. p. 107-111

Light, P., \& Littleton, K. (1999). Social processes in children's learning. UK and New York: Cambridge University Press. Reviewed by Binda, K.P. 113-117

\section{Volume 30, Number 1, 2001}

Binda, K. P. Aboriginal education in comparative and global perspectives: What has research and practice done for aboriginal education in Canada. pp.1-16 Keywords: Canada; aboriginal education; decentralization; ideological concern. 
Ezeife, A. N. Integrating the learner's schema, culture, and environment into the science classroom: Some cases involving traditional and aboriginal societies. pp. $17-44$

Keywords: Canada; aboriginal education; aboriginal learners; science education; culture; environment.

London, N. A. Curriculum and pedagogy in the development of colonial imagination: A subversive agenda. pp. 45-76

Keywords: Trinidad and Tobago; colonial education; curriculum development; hidden agenda; racism.

Sauder, R. Educational NGOs and accountability in South Africa: Continuity and dissonance. pp.77-104

Keywords: Sub-saharan Africa, NGO's; dependency; accountability; efficacy; cultural clashes.

Rezai-Rashti, G. Beyond the margins: Pushing the boundaries of multicultural and multilingual education in Toronto. pp.105-128

Keywords: Toronto, Canada; minority language teaching; static and essentialized culture information; faulty mainstream education.

\section{Book Reviews}

Ellsworth, E. (1998). Teaching positions: Difference, pedagogy and the power of address. New York: Teachers College Press. Reviewed by Kanu, Y. p.129134

Taylor, J. (2001). Union learning: Canadian labour education in the Twentieth century. Toronto: Thompson Educational Publishing. Reviewed by Spencer, B. p.135-138

\section{Volume 30, Number 2, 2001}

Anderson, G., Cooney, G. \& Langevin, J. Canadian support for management education internationally: Lessons learned. pp.1-34

Keywords: Canada and China; sustainability; exchange program; link at university level.

Dhesi, A. Determinants of post-school choice in India- A discriminant analysis. p.35-64

Keywords: Punjabi, India; higher education choice; parental involvement impact on children's higher education.

Dlamini, N. Can the empire's tools even dismantle the empire's house? Teacher education and the practice of identifications. pp.65-88

Keywords: Canada; preservice education; identity; marginal identity's impass; white supremacy on progressive education. 
Lam, J. Language proficiency controversy: Touching on the very core of school reforms in Hong Kong. pp.89-108

Keywords: Hong Kong; teachers' education proficiency; school reform; students' performance.

\section{Book Reviews:}

Bray, Mark \& Lee, W.O. (Ed.). Education and political transition: Themes and experiences in East Asia ( $2^{\text {nd }}$ ed.). Hong Kong: Comparative Education Research Centre. Reviewed by Bjork, C. p.109-112

Taylor, A. (2001). The politics of educational reform in Alberta. Toronto: University of Toronto Press. Reviewed by Lam, J. p.113-115

Welton, M. R. (2001). Little mosie from the margaree: A biography of Moses Michael Coady. Toronto: Thompson Educational Publishing. Reviewed by Spencer, B. p.117-119

\section{Volume 31. Number 1, 2002}

Bruno-Jofre, R. \& Henley, D. The Canadian Education Industry: An historical critique of Education as merchandise. pp.1-17

Keywords: Canada; education industry; education for profit policy.

Kawasaki, K. A cross-cultural comparison of English and Japanese linguistic assumptions influencing pupils' learning of science. pp.19-51

Keywords: Canada and Japan; languages' impacts on science education; linguistic influence.

Lee, M. W. The influence of cultural dimensions on collaboration in a crosscultural program. pp.53-72

Keywords: Canada and Egypt; cross-cultural influences; educational program; international education.

Smith, W. J. \& Foster, W. F. Cooperative governments and Tirisano: Templates for transformation of Education in South Africa. pp.73-114

Keywords: South Africa; education reform; equality; education policy research.

\section{Book Reviews}

Benjamin, L. (2001). Reforming education: From origins to outcomes. London and New York: RoutledgeFalmer. Reviewed by Schellenberg, M. p.115-119 


\section{Special Issue on Indicators of Education Systems (INES)}

McEwen, N. International comparisons of education systems. pp.1-16

Keywords: International; comparisons of OECD programs; INES.

Kadar-Fulop, J. Indicators of education systems. pp.17-32

Keywords: INES: relevant policy on data collecting; data gaps; outcomes; limitations

Owen, E. H., Moskowitz, J. \& Stephens, M. Measuring learner outcomes. pp.3354

Keywords: INES: comparative assessments; education policy; learner outcomes; reading literacy

Broucker, P. Education and socio-economic outcomes. pp.55-84

Keywords: International comparisons; socio-economic outcomes; equityschool-work transition; continuing education; human capital.

Hendriks, M. A. Cross-national indicators on teachers and the conditions of teaching. pp. 85-109

Keywords: International learning environment; educational success; preservice training; teacher quality and salaries.

Hodgkinson, G. D. \& Spencer, A. The role and relevance of INES in Canada. pp.111-122

Keywords: Canada; Interprovincial/territorial indicators programs INES.

Crocker, R. Observations on the INES symposium. pp.123-130

Keywords: Local/parochial education; INES scope; quality; ambition.

McEwen, N. Quo vadis INES? pp.131-146

Keywords: INES: purposes; policy; current issues; future development.

\section{Volume 32, Number 1, 2003}

\section{Editorial}

Krugly-Smolska, E. Where's the theory? p.v-x

\section{Articles}

Majhanovich, S. Making sense of decentralization in education using a comparativist lens. pp.1-18

Keywords: Ontario; Canada; decentralization; international education: world education systems.

Sims, L. Education for re-creating civil society: Working towards sustainable development, political voice and safety. pp.19-44 
Keywords: Latin-America; Mexico; democracy; civil society; educational policy.

Sloane-Seale, A. Transitional barriers for aboriginal post-secondary students in Manitoba: Implications for access to education. pp.45-76

Keywords: Canada; post-secondary education; aboriginal learners; educational outcomes; social and community integration.

Valenzuela, J. R. \& Gallardo, K. E. Problem-based learning in an online comparative education graduate course. pp.77-105

Keywords: Latin-America; Mexico; problem-based learning; peer interaction; comparative education via electronoc forums; ; effectiveness of collaborative learning.

\section{Volume 32, Number 2, 2003}

Howe, E. R. Curriculum, teaching and learning within the context of comparative, international and development education. pp.1-14

Keywords: Canada; Japan; international cooperation; education exchanges; cross-cultural understanding; global and local dialectics.

Lam, J. Organizational learning: A comparison of Hong Kong and Taiwan schools. pp.15-38

Keywords: Hong Kong; Taiwan; school systems; bipolar distribution; organizational learning process; collective learning, impacts of education reforms.

Li, X. Unveiling the hidden curriculum: Beliefs in the ESL context. pp.39-58

Keywords: Canada; beliefs impact on hidden curriculum; culture issues in ESL settings.

Samuel, E. The hidden curriculum: South Asian students' experiences in Canadian academe. pp.59-90

Keywords: Canada; South Asians; Eurocentric biased; hidden curriculum; racism; South Asian learners in Canadian unverisities.

\section{Book reviews}

Manzer, R. (2003). Educational regimes and Anglo-American democracy. Studies in comparative political economy and public policy series. Toronto:

Hayhoe, R. (2004). Full circle: A life with Hong Kong and China. Hong Kong: Comparative Education Research Centre (CERC), Hong Kong University. Reviewed by Wang, H. pp. 95-99 


\section{Volume 33, Number 1, 2004}

Special Issue/Numéro spécial: Educational Restructuring on the Era of Globalization

Guest editor: Goli Rezai- Rashti

Introduction

Rezai- Rashti, G. pp. 1-6

Keywords: Globalization effects on education reform and changes.

Daniel, Y and A. I. Griffith. Institutional Change and the Principalship in an Era of Educational Reform. pp. 7-30.

Keywords: Western world; school principal's role; institutional issues; critical perspectives on educational reforms.

Davidson-Harden, A. Neoliberal elements of restructuring through the Ontario College of Teachers: An example of centralized marketization. pp. 31-44

Keywords: Ontario, Canada; government-ledmarketing of in-service teacher education; teacher governance restructuring.

Dehli, K. Parental involvement and neo-liberal government: Critical analyses of contemporary education reforms. pp. 45-74

Keywords: Ontario, Canada; educational policy shift; impact of parental involvement; government's interference; neo liberal/neo-consevative ideological.

Schellenberg, M. Globalization and Citizenship Education: Implications for the Nation State. pp. 75-98

Keywords: Spain, Manitoba, Canada; OECD; WTO; EC; NAFTA; impact of globalizing agencies upon citizenship education; globalization impact over education policy.

Wallace, J. Educational purposes economicus: Globalization and the Reshaping of Educational Purpose in Three Canadian Provinces. pp. 99-117.

Keywords: Alberta, British Columbia, Ontario; adverse impacts of globalization over education; effect of decreasing corporate taxes over education, healthcare, and equity policy.

\section{Volume 33, Number 2, 2004}

Dei, G.. S. and A. Asgharzadeh. Inclusive Education and Social Development in an African Context. pp. 1-30

Keywords: Africa; Ghana; difference and diversity; inclusive schooling in pluralistic context; power, status, authority and influence in education. 
Pitman, A. and F. A. Chishtie. Pakistan. The State, Religion and School Mathematics pp. 31-56.

Keywords: Punjabi; Pakistan; mathematics secondary curriculum contribution to ethical, cultural, and political development; issues on difficulty in curriculum reform.

Young, M. and W. Cassidy. The Impact of a Global Education Course on Students' Citizenship Attitudes and Behaviour. pp. 57-88

Keywords: Global education; impacts on students' involvement in local and world affairs; citenzenship attitudes and behaviour; overseas field study.

\section{Book Reviews}

Ghosh, R. and Abdi, A. (2004). Education and the Politics of Difference: Canadian Perspectives. Reviewed by Majid Malekan p. 89

Bray, M. (Ed.) (2003). Comparative Education: Continuing Traditions, New Challenges, and New Paradigms. Reviewed by Anthony N. Ezeife p. 95

Bray, M. \& Koo, R. (Eds.) (2004) Education and Society in Hong Kong and Macao: Comparative Perspectives on Continuity and Change. Reviewed by Y. L. Jack Lam p. 99

Ninnes, P. \& Hellsten, M. (2005) Internationalising Higher Education: Critical Explorations of Pedagogy and Policy. Reviewed by Greg Burnett. p. 103

\section{Volume 34, Number 1, 2005}

A special issue of the journal, Canadian and International Education (CIEJ) on: Values, Human Rights and Citizenship Education in Transnational Perspectives Un numéro spécial de la revue, Éducation canadienne et internationale (RÉCI) sur: Éducation à la citoyenneté, aux valeurs et aux droits de la personne en perspectives transnationales

Guest editors: Yvonne Hébert (U. Calgary), Glen Eyford (U. Alberta), France Jutras (U. Sherbrooke)

Hébert, Y., G. Eyford, and F. Jutras. The Values Debate at the Nexus of Transnational Perspectives on Human Rights and Citizenship Education. pp. $1-11$

Keywords: Canada, transnational; introduction to values; human rights; citizenship education; post-colonial and pedagogical perspectives.

Jutras, F. L'éducation à la citoyenneté : une responsabilité désormais explicite à l'école québécoise d'accord, mais au nom de quelles valeurs? pp. 12-22 
Mots-clés: Québec, Canada; citoyenneté; objectifs de l'éducation; orientation de la citoyenneté.

Keywords: Quebec, Canada; citizenship education goals; citizenship orientation.

Wu, J. Z. Bilingual Education in Western Canada and Chinese Language Minority Students' Self Perceptions of their Citizenship and Ethnicity. pp. 23-30

Keywords: Western Canada; bilingual education models; program's structure and contents impact on minority students.

Lévesque, S. Conceptions historiques et identitaires des élèves francophones et anglophones de l'Ontario à l'époque post-11 septembre. pp.31-41

Mots-clés: Les francophones et anglophones du Canada; signification des évènements historiques (après le 11 septembre); meilleurs moyens pour enseigner les classes d'histoire et des études siciales.

Keywords: Canadian Anglophones and Francophones; historical events' significance (post september 11); better means for history and social studies classes.

Howe, B. Citizenship Education for Child Citizens. pp. 42-49

Keywords: Canada; children as citizens in citizenship education; children rights, responsibilities, participation.

Chareka, O. and A. Sears. Discounting the Political: Understanding Civic Participation as Private Practice. pp. 50-58

Keywords: Canada: African immigrants; civic participation; political and non-political civic activities; engagement in civic activities.

Pouwels, J. Citizenship Education in Post Modern Society. pp. 59-67

Keywords: Views from Europe; internation human rights culture; human rights education; pedagogical and didactical perspectives on citizenship education.

Wilkinson, L. On the Intersectionality of Transnationalism and Citizenship. 68-77 Keywords: EU, USA, Canada; transnationalism - positive/negative perspectives; transnational migrants.

Mbele, C. R. Citoyenneté et valeurs dans l'Euroafrique. pp. 78-89

Mots-clés: Europe, Afrique; partenariat euro-africain; engagement de la citoyenneté.

Keywords: Europe, Africa; Eurafrica partnership; citizen's engagement.

\section{Volume 34, Number 2, 2005}

Kanu, Y. Decolonizing Indigenous Education: Beyond Culturalism: Toward Postcultural Strategies. pp. 1-20

Keywords: Manitoba, Canada; indigenous knowledges inclusion to school curriculum; strategies to improve aboriginal students' achievement in schools. 
Mujawamariya, D. and S. J. Ship. La guerre et le génocide de 1994: Impacts et nouveaux espoirs sur l'éducation des jeunes filles au Rwanda. pp. 21-40

Mots-clés: Rwanda; rôles des organisations des femmes; l'égalité des sexes; sensibilisation des problèmes entre les deux sexes.

Keywords: Rwanda; women organizations' roles; gender's equity; gender problems' awareness.

Zhang, L. Privatization Chinese Style: Tuition Reforms in China's Postsecondary Education. pp. 41-54

Keywords: China; growth and effects of privatization in education; improperand unbalanced devolution's problems and issues.

Sloane-Seale, A. New Immigrants' barriers to participation in society and the economy. pp. 55-71

Keywords: Canada; services to immigrants; barriers to immigrants in social and economic insertion/integration; employment and education mediating influence.

Lafontaine, L.et Le Cunff, C. Recherche comparée sur la prise de parole de certains élèves du préscolaire au primaire en français langue maternelle en France et au Québec. pp.72-97

Mots-clés: Québec, Canada et France; l'enseignement de la compétence orale; compétence orale dans la socialisation; enseignement systématique.

Keywords: Quebec, Canada and Frrance; oral skills teaching; oral skills in socialization; systematic teaching.

\section{Book Reviews}

Kibler, A. (2005). Implementation of Educational Policies for Minority Language Pupils in England and the United States. Oxford: Symposium Books. Pages: 132 Price: 42.00 USD (paper) Reviewed by Dr. Larissa Klein, University of Western Ontario. pp. 98

Sumon Kamal Tuladhar. (2004). The out-of-school children's program in Nepal: an analysis. Paris: International Institute for Education Planning, UNESCO. Reviewed by Amani Hamdan Alghamdi, PhD (University of Western Ontario) pp. 100

Lawn, Martin; Grosvenor, Ian (2005). Materialities of Schooling: design, technology, objects, routines. Oxford, UK: Symposium Books. 217 pp. ISBN 1-873927-30-4. Reviewed by Rick Kitto, (University of Western Ontario). pp. 102. 
Varghese, T. and D. P. McCusker. On Globalization and Ethnomathematics. pp. 1-11.

Keywords: India; mathematics teaching; using local cultural knowledge to offset borrowing curricula.

Ezeife, A. N. and T. Arivalagan. Technology Education and Economic Competitiveness in Developing Countries: The Sri Lankan Experience. pp. 12-27

Keywords: Sri Lanka; technology education for social and economic transformation.

Shultz, L. Disrupting Contemporary Child Slavery Through Organization Networks: The Possibilities and Barriers. pp. 28-45

Keywords: International child slavery; educational organization networks; networks' successes and barriers.

Wihak, C. Learning to Learn Culture: The Experiences of Sojourners in Nunavut. pp. 46-62

Keywords: Canada; multicultural competences; cultural immersions; keys to success in teaching and learning in Inuit communties;

Saul, R. \& C. James,. Framing Possibilities: Representations of black student athletes in Toronto media. pp. 63- 79

Keywords: Toronto, Canada; black, male adolescent athletes; media perception's impacts on individual/group performance.

Reimer, M. and Mueller, A. Accessing the Transition to Careers for Female Undergraduates in the Restructured University in New Brunswick.. pp. 8091.

Keywords: New Brunswick; non-traditional women students; needs, difficulties, successes.

\section{Book Essay}

Wilde, S. (Ed.). (2005). Political and citizenship education: International perspectives. Oxford, UK: Symposium Books. ISBN: 1873927 991. Pages: 144. Reviewed by Jan Sobocan (The University of Western Ontario). p. 92

\section{Volume 35, Number 2, 2006}

Presidential Address, 2006. Cecille DePass. Comparative Education in Changing Times: A View with a Southern Exposure. pp. 1-16

Keywords: Comparative education; inclusive approaches; unintentional exclusions. 
Larsen, M. Comparing Connecticut and Finland: Teacher Friendly Policies in an Age of Accountability. pp. 17-34

Keywords: Connecticut, USA and Finland; positive impacts of teacherfriendly policy on teachers' working conditions, teachers professional development, and on students achievement.

Pollock, K. Policy as Outcome: Inequities Generated from Unintended Policy Outcomes. pp. 35-47

Keywords: England; Teacher Recruitment Agencies; policy's negative impacts on outcomes.

Huang, J. and D. A. Klinger. Chinese Graduate Students at North American Universities: Learning Challenges and Coping Strategies. pp. 48-61.

Keywords: Canada; Chinese graduate students; challenges foreign students have to face; coping strategies.

Hirata, J. Does School/Site Based Management (SBM) in Japan Achieve its Policy Purposes? A Policy Analysis of Japanese Education Reform Regarding School Advisors and School Management Councils. pp. 62-75

Keywords: Japan; decentralisation; negative effects of partial, incomplete or insufficient devolution.

Wang, B. A Comparison of the Portrayal of Visible Minorities in Textbooks in Canada and China. pp. 76-94.

Keywords: Canada and China; minority groups portrayed in textbooks; impacts of implicit assumptions; caution in writing or using multicultural content textbooks.

\section{Book Reviews}

Gaine, C. \& Weiner, G. (2005). Kids in Cyberspace: teaching anti-racism using the internet in Britain, Spain and Sweden. Oxford: Symposium Books. Pages: 168 Price: f24.00 (US\$42.00) ISBN 187392745 2. Reviewed by Dr. Janette Hughes, University of Ontario Institute of Technology. p. 95

Zhang, Sheri (2006). Understanding modern China through its language and culture. Gatineau, QC: Asia Communications Québec Inc. Reviewed by Xuemei Li, Queen's University. p. 98

Crossley, Michael; Herriot, Andrew; Waudo, Judith; Mwirotsi, Miriam; Holmes, Keith; \& Juma, Magdallen (2005). Research and evaluation for educational development: Learning from the PRISM experience in Kenya. Oxford, UK: Symposium Books. 144 pages. ISBN 187392720 7. Reviewed by Lucy Karanja (University of Western Ontario) p. 103 
Majhanovich, S. and L. Zhang. The Comparative and International Education Society of Canada (CIESC). pp. 1-14

Keywords: CIESC historical overview; past and present members' works; progress and future; international participation.

Martinovic, D., S. Windle, \& N. Dlamini. Shifting from Ideal to Critical Multiculturalism in Canadian Teacher Education. pp. 15-38

Keywords: Ontario, Canada; diverse cultural background teacher candidates training; initiative program for teacher tudents.

Todd Rogers, W., L. Cheng , \& H. Hu ESL/EFL Instructors' Beliefs about Assessment and Evaluation. pp.39-61

Keywords: Canada, Hongkong, Beijing, China; ESL/EFL evaluation; teachers beliefs and practice on evaluation.

Coulter, K. Students' Organizations in Canada and Cuba: A Comparative Study. pp. 62-74.

Keywords: Canada and Cuba; student organizations; work and struggle for social justice and equality.

Geo-JaJa, M. A. and S. Azaiki. Poverty and Inequality in the Niger Delta: Is National Economic Empowerment and Development Strategy (NEEDS) the Answer? pp. 75-92

Keywords: Nigeria; market forces' negative effects on anti-poverty strategy; state intervention and social safety net roles.

Namukasa, I. and R. Buye. Decentralization and Education in Africa: The Case of Uganda. pp. 93-117

Keywords: Uganda; decentralization as transfer of fiscal responsibility; negative effects of corruption and mismagement on devolution.

\section{Book Reviews}

Bray, M.; Adamson, B. \& Mason, M.: Comparative Education Research. Approaches and Methods. Hong Kong: Comparative Education Reserach Centre And Springer, 2007. Reviewed by M. Jesus Martinez Usarralde, The Universidad de Valencia. p. 118

Sears, J. T. (Ed.). (2005). Gay, lesbian, and transgender issues in education: Programs, policies, and practices. Binghamton, NY: Harrington Park Press. Reviewed by Laura A. Bower (University of Nevada, Las Vegas) p. 121 Spring, J. (2006). Pedagogies of Globalization, The Rise of the Educational Security State. Mahwah, New Jersey: Lawrence Erlbaum Associates. Pages: 308. ISBN: 0-8058-5556-4. Reviewed by Zahra Deborah Buttar, University of Nevada Las Vegas. p. 123 


\section{Volume 36, Number 2, 2007}

Steinbach, M. Developing social capital: An insider look at the language learning and integration experiences of new Canadians. pp. 1-14

Keywords: Canada; ESL students; newcomer exclusion; shool embedded structures; social insertion through ethnic contacts.

Weber, L. Internationalization at Canadian Universities: Progress and Challenges. pp. 15-32

Keywords: Canada; university program for international students; newcomers' assistance and support.

Bélair, L. M. et C. Lebel. La persévérance chez les enseignants franco-ontariens. pp. $33-50$

Mots-clés: Ontario; facteurs de la persévérance professionnelle; groupes minoritaires; enseignants francophones.

Keywords: Ontario; professional perseverance factors; minority groups; francophone teachers.

Pollock, K. Differentiated Access to Teaching: Teacher Recruitment Agencies and Flexible Work Arrangements. pp. 51-70

Keywords: England; ESL teachers; recruitement agencies; hard working conditions.

Asanova, J. Seeing near and far: Balancing stakeholder needs and rights in Kazakhstan's educational reform. pp. 71-90

Keywords: Kazakhstan; education reform after breaking-up; standardized assessment program; right-based perspective in educational reform.

Zhang, S. and R. Anthony. Language and Culture Research in the Context of International Education and Second Language Acquisition, pp. 91-103

Keywords: Canada; qualitative and quantitative researchs; strengths and weaknesses in language acquisition; metho selection based on issues.

\section{Book Review}

Negotiating Transcultural Lives, Belongings and Social Capital among Youth in Comparative Perspective. Edited by Dirk Hoerder, Yvonne Hébert, and Irina Schmitt. University of Toronto Press, Toronto, Canada, 2005, pp. 259.

Reviewed by Donna Murray, University of Nevada, Las Vegas. p. 104

\section{Volume 36, Number 3, 2007}

Pitman, A. Presidential address - The Ideological and Economic Repositioning of Universities. 
Keywords: Canada; Australia; higher education fundings; marketization impacts on university qualities and research objectives.

Marianne L., Majhanovich, S. \& Masemann, V. Comparative Education In Canadian Universities

Keywords: Canada, International; comparative and international education in Canadian universities; growth and development prospects.

Carr, P. Educational institutions negotiating democracy and social justice: The (im)balance of power and accountability

Keywords: Relations between power and accountability; education for democracy; balance between power and accountability.

Tran, D., Chen, J., \& Mahmoudi, M. Index, Volumes 1 to 36 of the Canadian and International Education Journal.

\section{The Comparative and International Education Society of Canada}

La Société canadienne d'éducation comparée et internationale Founding Papers: 1967 : Discours fondateurs

Edited by M. Gillett, J. Katz, R. Lawson, A. F. Skinner

Acknowledgment

Foreword

Dr. J. Katz

Fr. E. Trudeau

4

5

7

The Founding Year of The Comparative and International

Education Society of Canada

Constitution of the Society

Greetings from Comparative Education Societies Abroad

\section{Papers delivered at the Founding Meetings}

E. E. Stewart, The New Look in Ontario Education 35

Margaret Gillett, The New Look in Quebec Education 46

R. F. Lawson, A Critical Survey of Education in Western Canada 54

C. H. Smith, Observations on Adult Education in Mid-Western Nigeria

List of Founding Members

The Comparative and International Education Society of Canada

La Société canadienne d'éducation comparée et internationale Papers: 1968 : Discours

Edited by Publications Committee,

M. Braham, W. Brehaut, A. F. Skinner (Chairman), M. Zachariah 
Acknowledgement $\quad 5$

Foreword, J. Katz $\quad 7$

(Traduction française - L. Desjarlais) $\quad 8$

Introduction, A. F. Skinner 9

(Traduction française — L. Desjarlais) 11

Foreign Influences in Canadian Education

I. Scottish Influence, Andrew F. Skinner 13

II. French Influence, Louis-Philippe Audet 23

III. English Influence, Willard Brehaut 35

IV. American Influence, R. L. Schnell 45

A Survey of Comparative and International Education Resources

and Facilities in Selected English-language Colleges and

Universities in Canada, $\quad$ R. Magnuson 49

International Education: New Objectives and Strategies

Martena Sasnett 61

Papers by Members of Youth Panel

I. Peace Corps Volunteer Community Worker

Patricia Harkleroad

73

II. C.U.S.O. Volunteer Teacher

Bruce Bailey 75

III. C.U.S.O. Volunteer Teacher
Barbara A. Geddes

IV. Independent World Traveller -

Rae McCombs

V. V. S. 0. Youth Officer - J

J. Ian Prattis

82

Conference Program

The International Mosaic in Canadian Education 87

Executive Committee: 1968-69 89

The Comparative and International Education Society of Canada

La Société canadienne d'éducation comparée et internationale

Papers: 1970 :Communications

Editor: Andrew F. Skinner

Acknowledgement 5

Foreword, Andrew F. Skinner (English Version) 7

Comparative Studies in Higher Education

(Version française) $\quad 10$

I. Higher Education in Australia and Canada:

A Comparative Study, Robin S. Harris

II. Community Colleges: A Comparative Investigation 
III. Federal-Provincial Relationships and Higher Education:

The Comparative Issues for Canada,

Leonard Marsh

IV. L'Evolution des Structures Universitaires au Canada, Lucien Michaud

V. Comparative Education in the Preparation of Teachers

1. Factors to be Considered and Some Suggestions, Harold Entwistle

2. Purposes and Perspectives,

David Smith

VI Changing Roles and Functions in Universities

1. Criteria of Decision on University Role

Robert Lawson

2. The Changing Canadian University: From Newman to von Humboldt

Roger Magnuson

Published and Unpublished Research of Members: 1968 - 70

Compiled by Roger Magnuson

Conference Program, May 1970

Comparative Studies in Higher Education

115

Executive Committee: 1970 - 71

Dien Tran, Ph.D. was involved with the CIE Journal since 1994. Currently, he divides his time between overseas lectures on Social Integration and Participation and the administration of the Journal. He can be contacted at dtranciesc@yahoo.ca

Chen Jie, M.Ed. is currently teaching TOEFL and IELTS courses. Her research focus is the TOEFT iBT preparation courses. She approaches the Comparative Education field via Language teaching in different environments and settings espeially in China and Canada. She can be contacted at chj8301@gmail.com

Mohsen Mahmoudi is a Ph.D. Candidate. His area of concentration is the Comparative and Multicultural Education in the Middle East and Canada. He can be contacted atmmahmoudi@uwo.ca 